\title{
Multistage shortening in the Dauphiné zone (French Alps): the record of Alpine collision and implications for pre-Alpine restoration
}

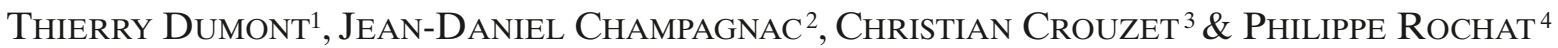

Key words: External Western Alps, multistage deformation history, Hercynian fabric reactivation, Tethyan rifting, inversion tectonics, lateral escape, 3D modelling

\begin{abstract}
Three-dimensional modelling tools are used with structural and palaeomagnetic analysis to constrain the tectonic history of part of the Dauphiné zone (external Western Alps). Four compressive events are identified, three of them being older than the latest Oligocene. Deformation D1 consists of W-SW directed folds in the Mesozoic cover of the study area. This event, better recorded in the central and southern Pelvoux massif, could be of Eocene age or older. Deformation D2 induced N-NW-oriented basement thrusting and affected the whole southern Dauphiné basement massifs south of the study area. The main compressional event in the study area (D3) was WNW oriented and occurred before $24 \mathrm{Ma}$ under a thick tectonic load probably of Penninic nappes. The D2-D3 shift corresponds to a rapid transition from northward propagation of the Alpine collision directly driven by Africa-Europe convergence, to the onset of westward escape into the Western Alpine arc. This Oligocene change in the collisional regime is recorded in the whole Alpine realm, and led to the activation of the Insubric line. The last event (D4) is late Miocene in age and coeval with the final uplift of the Grandes Rousses and Belledonne external massifs. It produced strike-slip faulting and local rotations that significantly deformed earlier Alpine folds and thrusts, Tethyan fault blocks and Hercynian structures. 3D modelling of an initially horizontal surface, the interface between basement and Mesozoic cover, highlights large-scale basement involved asymmetric folding that is also detected using structural analysis. Both, Jurassic block faulting and basement fold-and-thrust shortening were strongly dependent on the orientation of Tethyan extension and Alpine shortening relative to the late Hercynian fabric. The latter's reactivation in response to oblique Jurassic extension produced an en-échelon syn-rift fault pattern, best developed in the western, strongly foliated basement units. Its Alpine reactivation occurred with maximum efficiency during the early stages of lateral escape, with tectonic transport in the overlying units being sub-perpendicular to it.
\end{abstract}

RESUME

L'histoire des deformations dans un secteur du Dauphiné (zone externe des Alpes occidentales) est précisée en utilisant à la fois l'analyse structurale, le paléomagnétisme et la modélisation $3 \mathrm{D}$. On y reconnait quatre évènements compressifs, dont trois antérieurs à l'Oligocène terminal. La deformation D1 se marque par des plis à vergence $\mathrm{W}$ à $\mathrm{SW}$ dans la couverture mésozoïque. Ce premier évènement, mieux connu dans la partie sud des massifs cristallins dauphinois, est antérieur à l'Eocène supérieur. La déformation D2 a produit des chevauchements de socle orientés vers le $\mathrm{N}$ et le NW dans les massifs dauphinois situés au Sud du secteur étudié. Mais ce dernier a été principalement marqué par le raccourcissement D3 orienté ESE-WNW, qui s'est produit avant 24 Ma sous une importante couverture tectonique de nappes penniques. Ce changement entre D2 et D3 marque une évolution importante de la collision alpine, d'abord dominée par la subduction continentale en conséquence directe de la convergence N-S entre Afrique et Europe, puis par l'échappement latéral vers l'ouest qui a généré l'arc des Alpes occidentales. Cette réorganisation oligocène a aussi provoqué l'activation du décrochement insubrien. La dernière déformation D4, d'âge Miocène supérieur, a accentué les bombements de socle des massifs des Grandes Rousses et de Belledonne, entre lesquels des mouvements décrochants et des rotations ont distordu à la fois les structures alpines antérieures, les failles et blocs téthysiens et la foliation hercynienne. L'interface socle hercynien/couverture mésozoïque, qui était initialement plan et horizontal, a été construit en 3D. Le réseau des blocs téthysiens y apparaît déformé par des failles et des plis de socle. Les observations de terrain montrent que l'orientation du grain hercynien a largement influencé la nature et la localisation des structures distensives et compressives. Les dépocentres jurassiques se seraient disposés en échelon à cause de l'obliquité de l'extension téthysienne par rapport à la foliation du socle. Durant la collision, cette dernière a été le plus intensément réactivée lorsque la contraction lui était subperpendiculaire, c'est à dire à partir de l'Oligocène quand le régime en échappement latéral vers l'Ouest a été établi.

\section{Introduction}

The origin of the arcuate shape of the Western Alpine fold belt is still debated. Some models regard it as inherited either from the shape of the Jurassic margins (Lemoine et al. 1989) or from the shape of the Adriatic indenter (Coward \& Dietrich 1989). Other authors propose that the arc was created during Alpine collision due to indentation and lateral escape (e.g. Tapponnier

\footnotetext{
${ }^{1}$ CNRS, Université Joseph Fourier, Laboratoire de Géodynamique des Chaînes Alpines (UMR 5025), 1381 rue de la Piscine, F-38400 St Martin d'Hères. Email: Thierry.Dumont@ujf-grenoble.fr

${ }^{2}$ Institute of Mineralogy, University of Hannover, Callinstrasse 3, D-30167 Hannover.

${ }^{3}$ allée des Bayardines, 38530 Pontcharra.

${ }^{4}$ Total, BP730, F-92007 Nanterres cedex.
} 


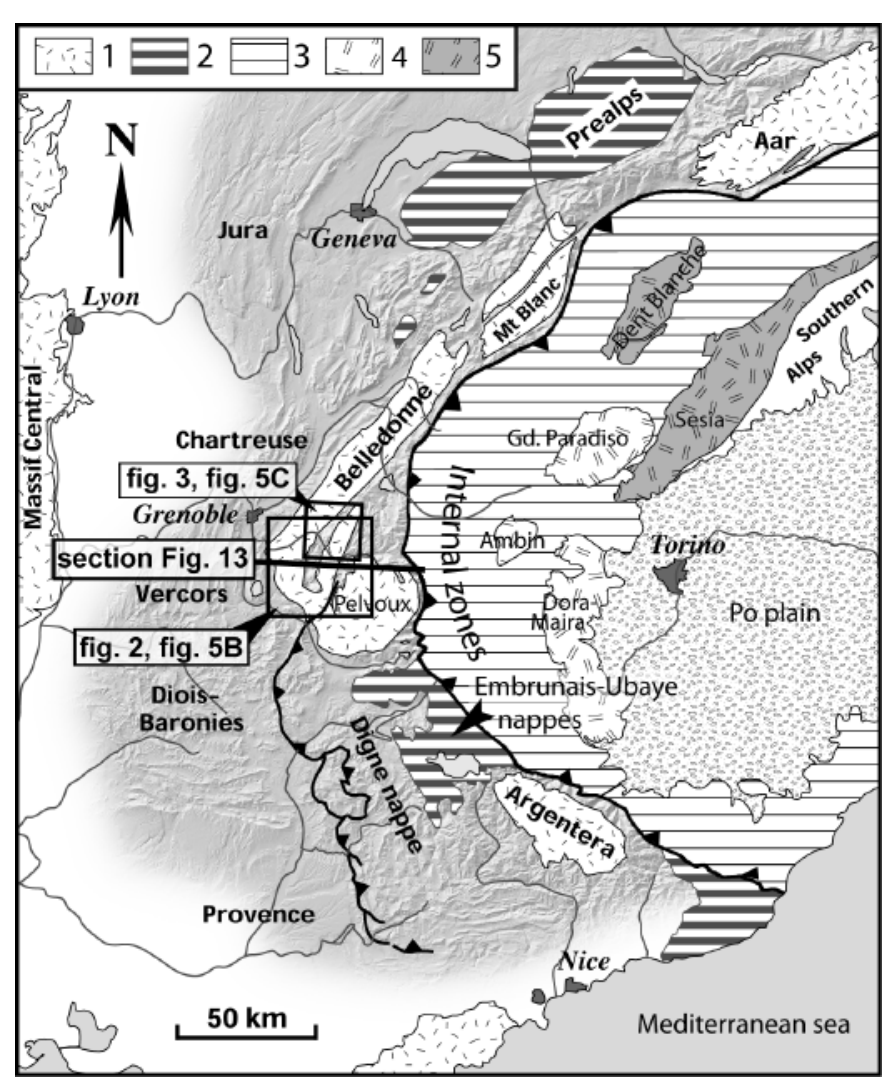

Fig. 1. Location of the study area. Shaded relief: deformed Meso-Cenozoic cover of the External zone; 1: External basement massifs (Hercynian basement); 2: Exotic flysch and klippe; 3: nappes of the Internal zones; 4: Internal basement massifs, European origin; 5: Crystalline basement, Austro-Alpine origin.

1977; Vialon et al. 1989). However, various associated driving mechanisms are involved: counter-clockwise rotation of the indenter and/or of the Penninic foreland (Ricou \& Siddans 1986; Choukroune et al. 1986; Laubscher 1988; Thomas et al. 1999), change in relative motion of the indenter (Schmidt \& Kissling 2000; Lickorish et al. 2002; Ford et al.2006), or indenter-induced body forces with constant plate motion (radial outward model of Platt et al. 1989a, Ratschbacher 1989). The arcuate trend is outlined by the trace of the Internal Alpine units and their western boundary, the so-called Frontal Pennine thrust (Butler 1992), Briançonnais Frontal Thrust (Sue \& Tricart 2002), Penninic Basal Contact (Ceriani \& Schmid 2004), and Basal Penninic Fault (Ford et al.2006). By contrast, the trend of the external crystalline massifs shows an abrupt change from NE-SW to NW-SE, where the study area is located (Fig. 1). Belonging to the Dauphiné zone, it shows high Hercynian basement massifs with Mesozoic series pinched in roughly N-S trending synclines (Fig. 2). In the literature these structures have been described as inverted Jurassic basins (Barféty et al. 1979; Lemoine et al. 1981). Alpine shortening was strongly influenced by the Mesozoic rift pattern (Tricart \& Lemoine 1986), which needs a detailed understanding of compressional deformation history to be restored. Because the orientation of rift structures (tilted blocks) and the transport direction along the major thrusts changed through time (Graciansky \& Lemoine 1988; Claudel \& Dumont 1999; Ceriani et al. 2001), the final geometry must be studied in three dimensions, and maintaining consistency in the deformation history between large-scale and small-scale structures is of utmost importance. In this study field data and palaeomagnetic records are considered in a regional framework improved by the use of synthetic imagery (synthetic aerial views and 3D geological maps). Additionally, 3D modelling of the Hercynian basement/Mesozoic cover interface was carried out because this initially flat reference surface provides a marker for finite deformation during the Alpine cycle (Tethyan extension plus Alpine shortening). This multidisciplinary approach leads to a reappraisal of the relative effects of Hercynian heritage, Mesozoic rifting and Alpine shortening on the present geometry. It also facilitates proposing time constraints for some stages of Alpine exhumation in this area.

\section{Structural and stratigraphic framework of the northern Dauphiné}

Many previous studies focused on structures and deformation processes (Vernet 1965, 1974; Vialon 1974, 1986; Gratier et al. 1973, 1978; Gratier \& Vialon 1975, 1980; Lamarche 1987; Gillcrist 1988; Grand 1988; Crouzet et al. 1996). The northern Dauphiné region shows $\mathrm{N}-\mathrm{S}$ to NE-SW trending massifs composed of Cambro-Ordovician to early Carboniferous metamorphic basement and intruded by late Variscan granites (Guerrot \& Debon 2000), locally with late Carboniferous cover of molasse and conglomerates. The Palaeozoic basement together with these molasse sediments are truncated by a regional unconformity overlain by thin but widespread Triassic shallow marine carbonates, and by deeper marine Liassic to Upper Jurassic limestones and marls (Barféty 1988; Dumont 1998). The Mesozoic series are pinched between the basement massifs (Fig. 2; Fig. 3) and deformed under zeolite to lower greenschist metamorphic facies during Alpine shortening (see references in Crouzet et al. 2001a). The overall structure was first regarded as Alpine folds involving the basement (Vernet 1965), then later as remnants of Tethyan tilted blocks (Barféty et al. 1979; Lemoine et al. 1981; Barféty \& Gidon 1983, 1984) more or less affected by tectonic inversion processes in a brittle setting (Grand et al. 1985; Lemoine et al. 1986; Gillcrist et al. 1987). However, the occurrence of large-scale basement folds, already noted by previous authors (e.g. Vernet 1965), has been highlighted more recently (Ford 1996; Dumont et al. 1997).

The tectono-sedimentary analysis of the Mesozoic record documents Alpine and pre-Alpine deformation in the following ways:

- The sharp Triassic transgression seals Hercynian structures and makes it possible to distinguish between Hercynian and Alpine cleavages; 


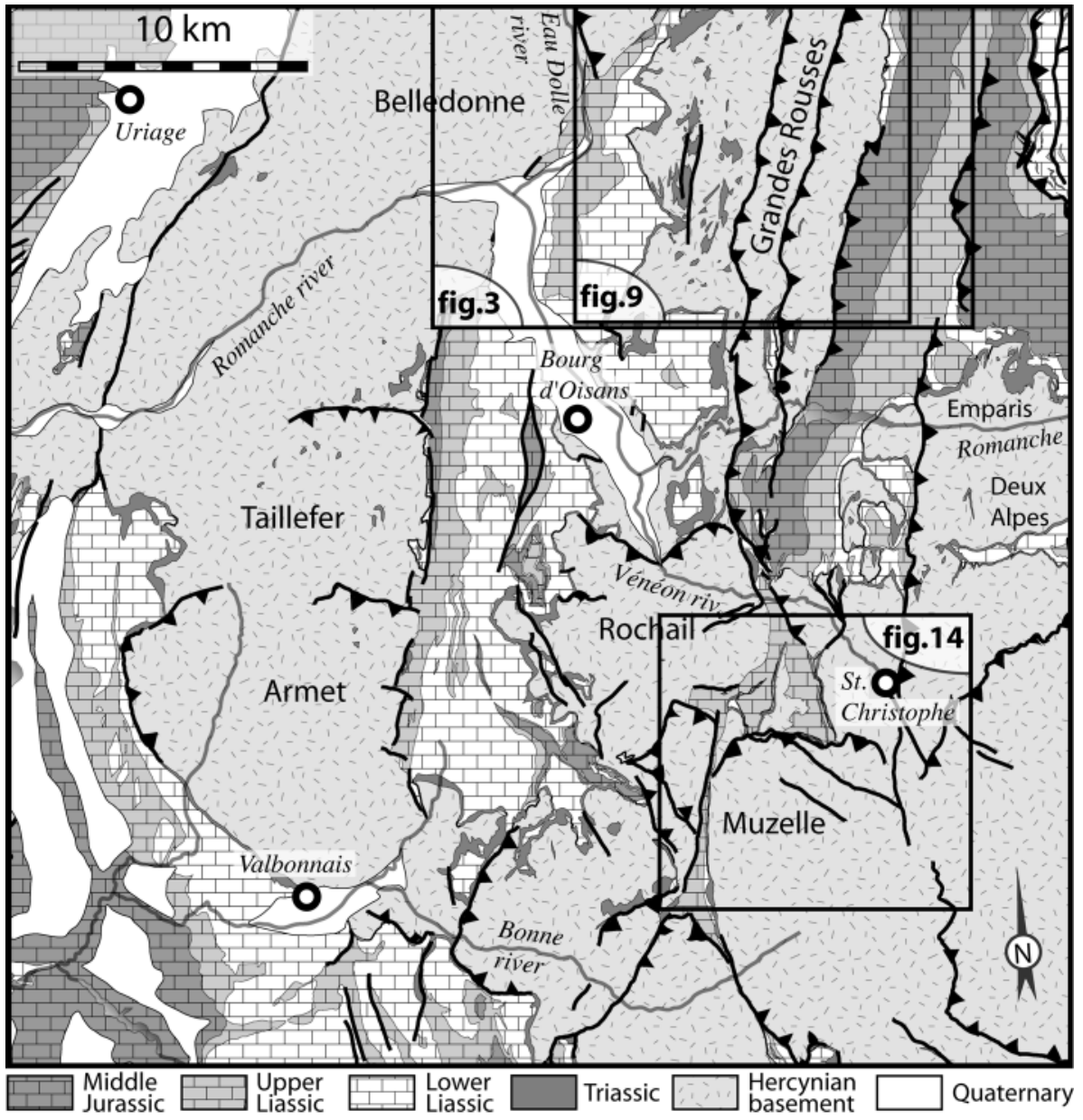

Fig. 2. Structural map of the central Dauphiné region, corresponding to the 3D model of Fig. 5b.
- The constant thickness and facies of the widespread lower Triassic dolomites, which were deposited in peritidal environments, demonstrate that the whole domain was very flat and horizontal at that time. Thus, the present geometry of the transgression surface is the result of Mesozoic extension combined with Alpine shortening;

- The distribution, stratal patterns and palaeotectonic features within Liassic syn-rift sediments help to reconstruct the shape of Jurassic extensional blocks (Barféty \& Gidon 1983; Lemoine et al. 1986; Barféty 1988, and refs. herein). The vertical movements and extensional fault kinematics can be deduced from analysis of palaeobathymetry and sequence stratigraphy (Roux et al.1988; Chevalier et al.2003). Since the Triassic series contain few evaporites, the lower part of the syn-rift sequence generally remains attached to the basement, such that the contribution of Mesozoic rift deformation on the geometry of the basement blocks of this area can be evaluated.

Despite Alpine shortening, the Mesozoic rift structures are still clearly visible on E-W profiles across the Bourg d'Oisans halfgraben (Fig. 4; Fig. 5a). However, the 3D structure is poorly understood. Due to its present rhomb shape, it has been tentatively interpreted as a pull-apart basin (Grand et al. 1985; Dumont \& Grand 1987), but the amount of Alpine deformation was probably underestimated.

\section{Compressional structures and deformation history}

Multistage deformation is documented by Gratier \& Vialon (1980), with strong reorientation of fold axis near the Tethyan-inherited Taillefer-Belledonne buttress due to increasing strain intensity (Gratier et al. 1978). Here we propose a sequence of tectonic events which is similar to the one identified by Sue et al. (1998) in a nearby area, but with different ages (see discussion in §5). Our outcrop observations focus on the basement-cover interface, whose 3D regional-scale shape is described in $\S 4$. We investigated the structural relationships of this interface with two types of structures: (a) Alpine compressive structures in the overlying Mesozoic sedimentary cover, and (b) the late Hercynian foliation in the underlying basement, which is locally involved in Alpine folds but which can be restored together with the originally horizontal basement-cover interface. 


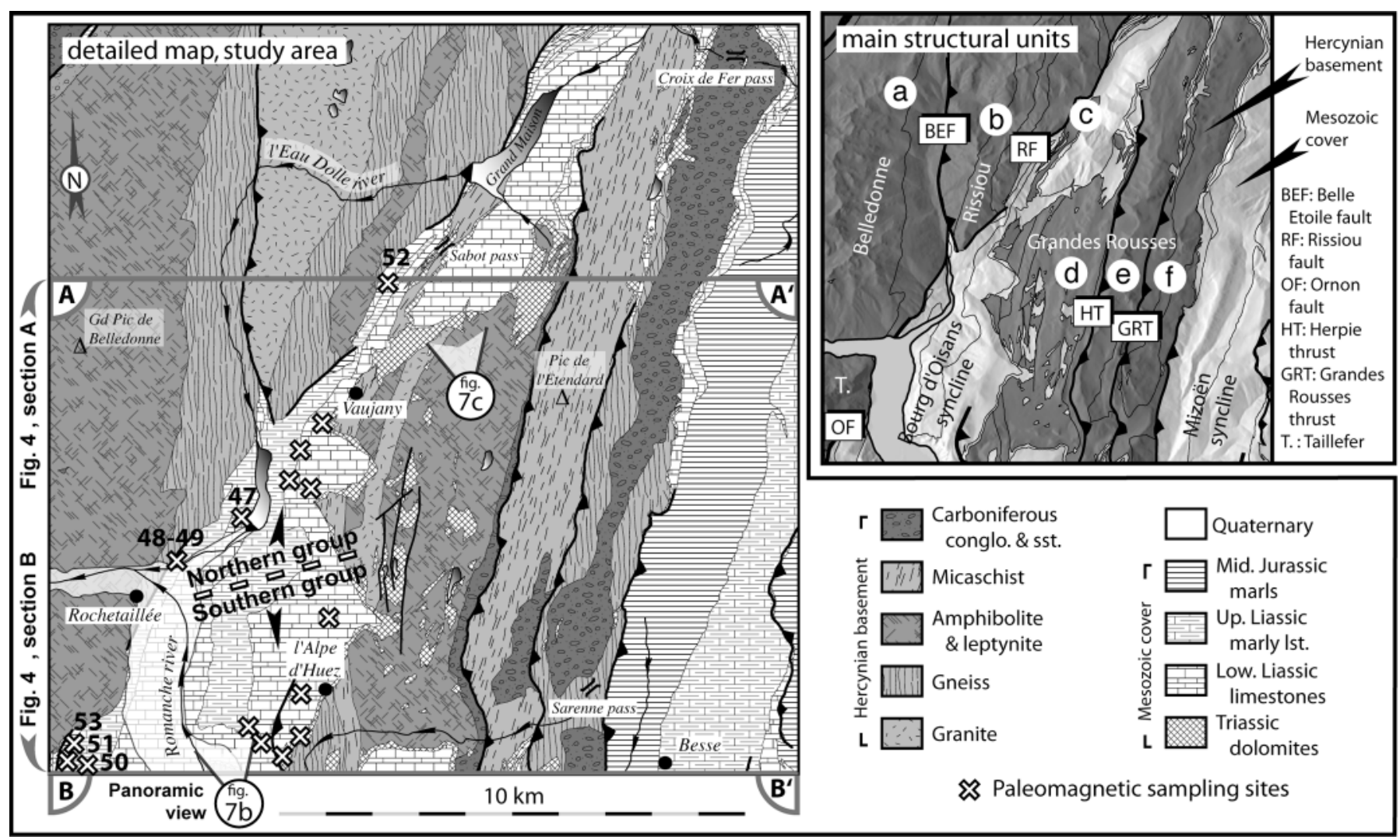

Fig. 3. Left: Geological map of the main study area, corresponding to the 3D model of Fig. 5c. Locations of Fig. 4 (sections) and Fig. 7 (panoramic views) also shown. Paleomagnetic sampling sites located: numbers refer to previously unpublished data (Table 1 and text), while other sites are described in Crouzet et al. (1996, 1999 \& 2001a). Right: cartoon of the same area showing the main structural units: (a): Belledonne; (b): Rissiou; (c): Sabot; (d): Huez-western Grandes Rousses; (e): central Grandes Rousses; (f): eastern Grandes Rousses (same units as in Fig. 4, 5c \& 12a).

\subsection{Deformation sequence recorded in the Mesozoic cover}

Alpine deformation was polyphase and the cleavages developed during folding under low to medium grade metamorphic conditions (Gratier \& Vialon 1980; Aprahamian 1988; Nziengui 1993; Crouzet et al.2001a). Fold trends and cleavages measured within the Triassic and lower Liassic formations around the Grandes Rousses bulge (Fig. 6 and examples in Fig. 7) document four folding and thrusting events (D1 to D4, in order of increasing age):

- D1 produced WSW- to SW-recumbent folds only visible in the southern part of the study area (Auris fold; site 13, Fig. 6). It is locally overprinted by north-directed D2 crenulation, and by D3 westward shortening (Fig. 7a). A similar deformation history is known further south (Sue et al. 1998 and § 6.4).

- D2 involves only the southern part of the study area and is much more developed further south (central and southern Pelvoux). It consists of north- to NW-directed, high-angle basement thrusts, which affect the Liassic cover only locally. These features indicate N-S to NW-SE shortening, which is parallel to the trend of the Alpine chain in this area. This particular feature will be documented and discussed below (§6.4).
- D3 is responsible for many of the observed structures, with both small-scale folding of Triassic beds attached to the basement and large-scale ductile deformation of the lower Liassic wedge, disharmonically folded above basement thrusts (Fig. 7b). D3 features are enhanced by the reactivation of basement foliation, which was suitably oriented for high-angle reverse faulting (e.g. the Herpie and La Garde thrusts: HT \& LGT, Fig. 4b \& 5a). D3 is top-W to top-NW oriented, but the orientation of fold axes vary significantly from south to north (Fig. 6). This curved path is due to D4 rotation, as shown by structural and palaeomagnetic data ( 3.2 and $\$ 5)$.

- D4 consists of open folds with steep axial planes and kink geometries, with local backward (eastward) fold and thrust features (Fig. 7b \& 7c). The associated cleavage S4 clearly overprints D3 structures along the road from l'Alpe d'Huez to Villard Reculas (Fig. 7b), in agreement with Vialon (1968) and Gratier et al. (1973). D4 folding is consistent with conjugate strike-slip faulting on both sides of the Rissiou basement block (Fig. 6, sites 4 to 6) and on the western slope of the Grandes Rousses massif, indicating an EW to $\mathrm{N} 100^{\circ}$ oriented maximum stress axis. D4 is probably coeval with the final uplift of the Grandes Rousses massif, 
which occurred recently according fission-track data (Sabil 1995).

\subsection{Alpine compressional structures in the shallow part of the basement}

Alpine folding affected both the basement-cover interface and the Hercynian foliation. In the hanging wall of the La Garde thrust (LGT, Fig. 7b), the Hercynian foliation is involved in a ramp anticline, as shown by the scatter of poles of Hercynian foliation along a small circle of the stereogram (Fig. 8). This small circle indicates a primary angle of no more than $20^{\circ}$ between the strike of Hercynian foliation before folding and the D3 Alpine fold axis measured in the sedimentary cover immediately above the interface. This low-angle obliquity is repeatedly observed in five locations from south to north (Fig. 9a, Fig. 10), with Hercynian foliation and D3 fold axis rotated together but maintaining about the same angle between both. This rotation of the D3 fold axis together with the Hercynian foliation, about $40^{\circ}$ clockwise from south to north, is due to the later Alpine event D4. This renewed E-W shortening also involved (Fig. 9b) conjugate strike-slip motion of the Rissiou and Alpe d'Huez faults (RF and AHF) and updoming of the Grandes Rousses bulge (Fig. 9c). Older Alpine structures such as D3 fold trends and basement thrusts (HT, GRT; Fig. 3, Fig. 9b) are rotated and involved in the bulge. Before rotation, the D3 structures and the Hercynian fabric were more rectilinear, and were slightly oblique to each other.

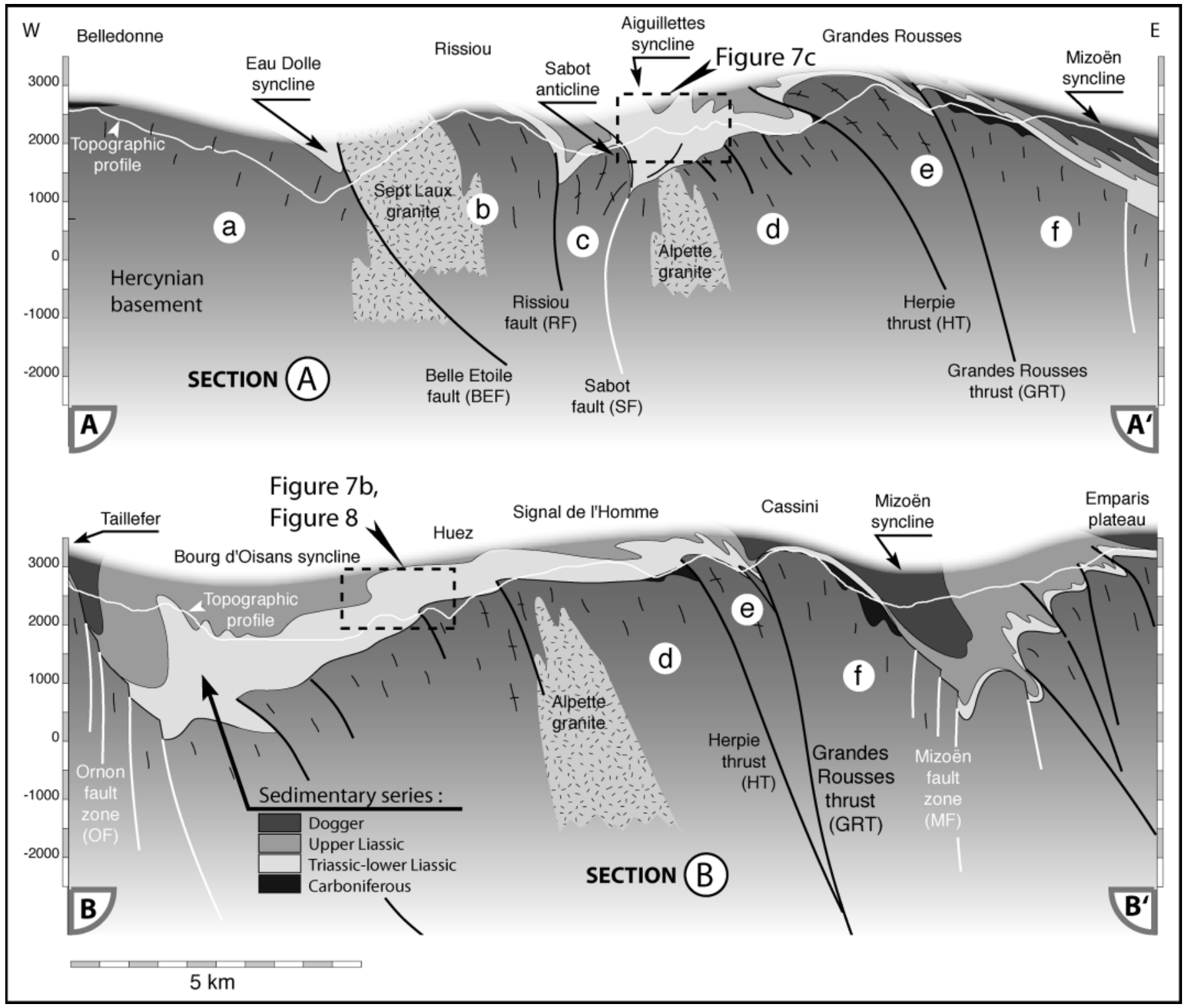

Fig. 4. E-W interpretative cross sections in the Bourg d'Oisans area (location Fig. 3). 


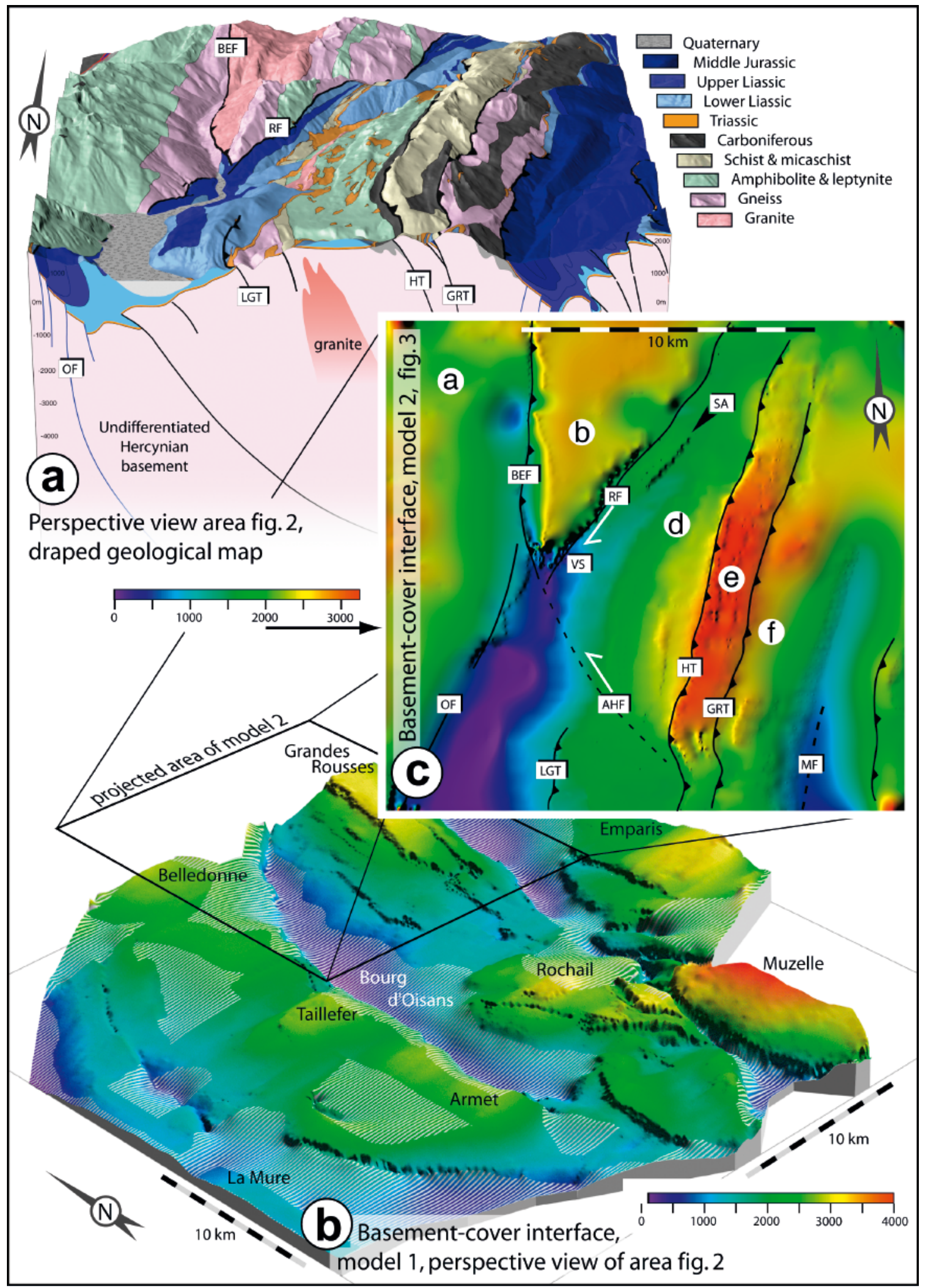

Fig. 5. a) Perspective geological map view from the South (same area as Fig. 3) combined with the interpretative cross-section of Fig. 4b. b) 3D model of the Basement-cover interface (BCI) in the area corresponding to Fig. 2, perspective view from SW. Shaded relief combined with rainbow colour scale for altitude. c) Detailed 3D model of the BCI in the main area of interest (corresponding to Figs. 3 and 5a). Altitude scale is different from fig. $5 \mathrm{~b}$.

Main Alpine features: AHF: Alpe d'Huez fault; BEF: Belle Etoile fault; GRT: Grandes Rousses thrust; HT: Herpie thrust; LGT: La Garde thrust; RF: Rissiou fault; SA: Sabot anticline; VS: Vaujany syncline; Main pre-Alpine (Tethyan) features: OF: Ornon fault zone; MF: Mizoën fault zone. 


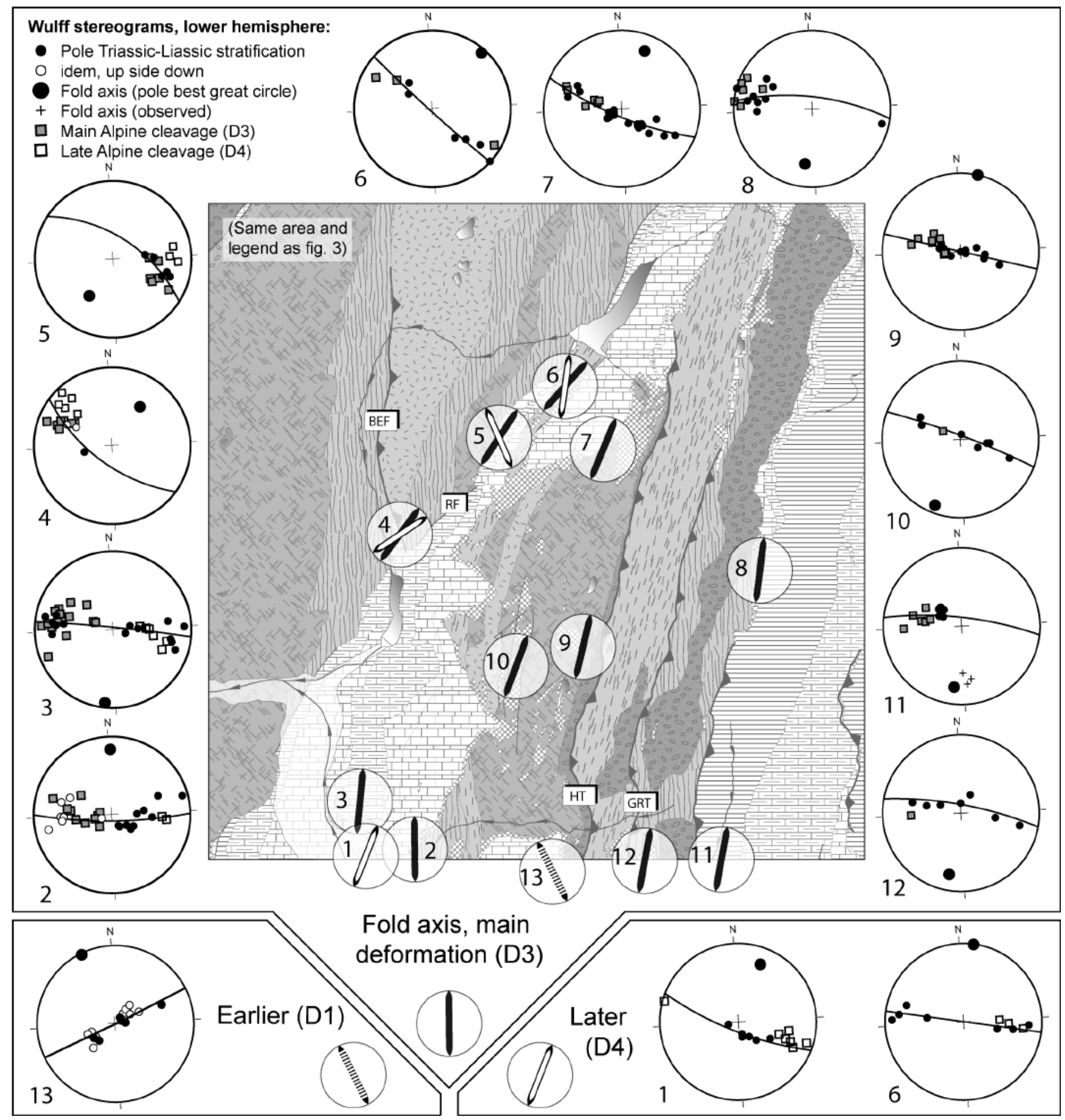

Fig. 6. Kinematic data from the Mesozoic sedimentary cover, mostly from Triassic and lower Liassic strata (sites numbers are different from Fig. 9). Outcrop pictures are given in Fig. 7. Most tectonic marks refer to deformation D3, locally overprinted by D4. A gradual clockwise rotation of F3 fold trends is observed from south to north, as in the basement structures (Fig. 9). This D4 deformation in the Grandes Rousses massif may be related with conjugate strike-slip motions of the southern BEF and RF suggested by steeply dipping F4 fold axes on both sides of the Rissiou block (sites 4 \& 5).

Sites location: (1) Côte Alamelle cliff, (2) road to l'Alpe d'Huez, (3) road from Huez to Villard Reculas, (4) 1 km north from Le Verney, (5) below Les Grandes Côtes, SW from the Sabot pass, (6) 0,5 km west from the Sabot pass, (7) near the Couard pass, (8) southern slope of Crête des Sauvages, (9) between Blanc lake and Milieu lake, (10) above Besson lake, (11) southern shoulder of the Chambon dam, below high water level (projected), (12) north of Sarenne pass, (13) between Les Courts, Combe Gillarde and Cluy pass (projected). 

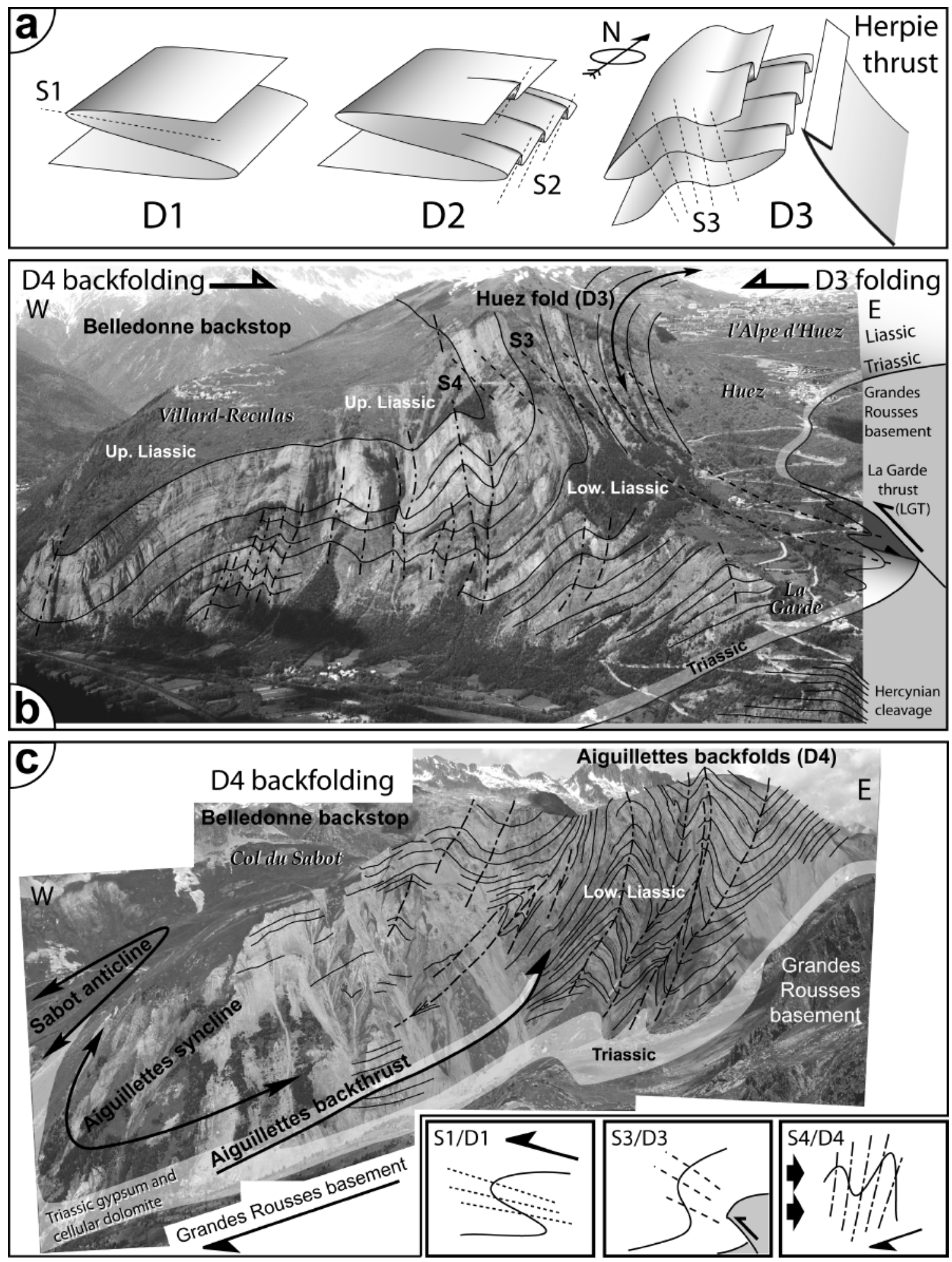

Fig. 7. Examples of multistage folding in the Liassic sedimentary cover of the study area, from north to south: a) Sketch of interferences observed in the southern part of the study area (Auris; site 13 of Fig. 6): the reverse limb of a D1 recumbent fold was deformed by D2 N-directed crenulation before D3 folding in the footwall of the Herpie W-directed thrust. b) The West-directed F3 Huez fold, surrounding the La Garde basement thrust and ramp anticline, is overprinted by D4 backward folding with kink geometry. The S4/S3 overprint can be observed along the Huez to Villard Reculas road. This area corresponds to sites 1,2 and 3 of Fig. 6. c) Backward D4 fold and thrust structures in the Aiguillettes thick lower Liassic series, East from the Sabot pass. The lower Liassic series surrounding the Sabot anticline and onlapping the Belledonne backstop is very condensed (Fig. 4a), which implies the occurrence of a hidden Liassic palaeofault between the Sabot anticline and the Aiguillettes syncline. 


\section{Large-scale present geometry of the Hercynian basement-Mesozoic cover interface}

\section{1 modelling the basement-cover interface in $3 D$}

As stated above, the present shape of the basement-cover interface represents the combined effects of Tethyan and Alpine deformations, because this surface was flat and horizontal 230 My ago before Jurassic extension (normal faulting, tilting) and Alpine shortening (folding, thrusting). This surface frequently has no Mesozoic sedimentary cover and is intersected by valleys, making it easy to model. Two 3D models of this basementcover interface were made using DEMs from the French Institut Géographique National (BD-Alti database) and 1/50000 scale geological maps from Bureau de Recherches Géologiques et Minières (BRGM), modified and georeferenced in NTF Lambert III (Vizille sheet, Barféty et al. 1972; La Grave sheet, Barbier et al.1973; La Mure sheet, Barféty et al.1988; St Christophe sheet, Barféty, Pêcher \& coll. 1984). The areas covered by these two models correspond to Fig. 2 and Fig. 3, respectively. The first larger model covers the Dauphiné and northern Oisans (Fig. $5 b ; 37 \times 37 \mathrm{~km}$ ). The second model focuses on the Grandes Rousses-Rissiou area (Fig. $5 \mathrm{c} ; 18 \times 18 \mathrm{~km}$ ). We used the following method:

- E-W topographic profiles were extracted every $350 \mathrm{~m}$ (model 1, Fig. 5b) or $250 \mathrm{~m}$ (model 2, Fig. 5c) from the DEM. Along each profile, the basement-cover interface was located from outcrops or its depth was estimated considering the thickness of the sedimentary cover. Gaps were preserved when such estimation was unreasonably constrained (e.g. central Bourg d'Oisans valley) or when a significant part of the basement was suspected to have been removed by erosion (e.g. Belledonne massif). In the latter case, the envelope surface of the highest preserved relief was taken as a minimum altitude value for the interface.

- The profiles were included in a 3D modelling box. The traces of interface from each profile were connected, giving patches which cover about $40 \%$ of the total area.

- Finally, an automatic interpolation was carried out (minimum curvature method, Surfer software) in order to fill the areas without data. These interpolated areas, lacking in geological constraints, are striped on Fig. 5b.

The models are presented in colour/altitude scale to show elevation (probably underestimated in the Belledonne massif), and lightened to enhance the relief. They can be rendered as a block-diagram (Fig. 5b) or map view (Fig. 5c).

\subsection{Characteristic features of the 3D models: Tethyan vs. Alpine influence}

The large model (Fig. 5b) shows relicts of the Jurassic halfgrabens (Bourg d'Oisans and Mizoën basins) which are N-S oriented and which are best preserved from Alpine shorten-

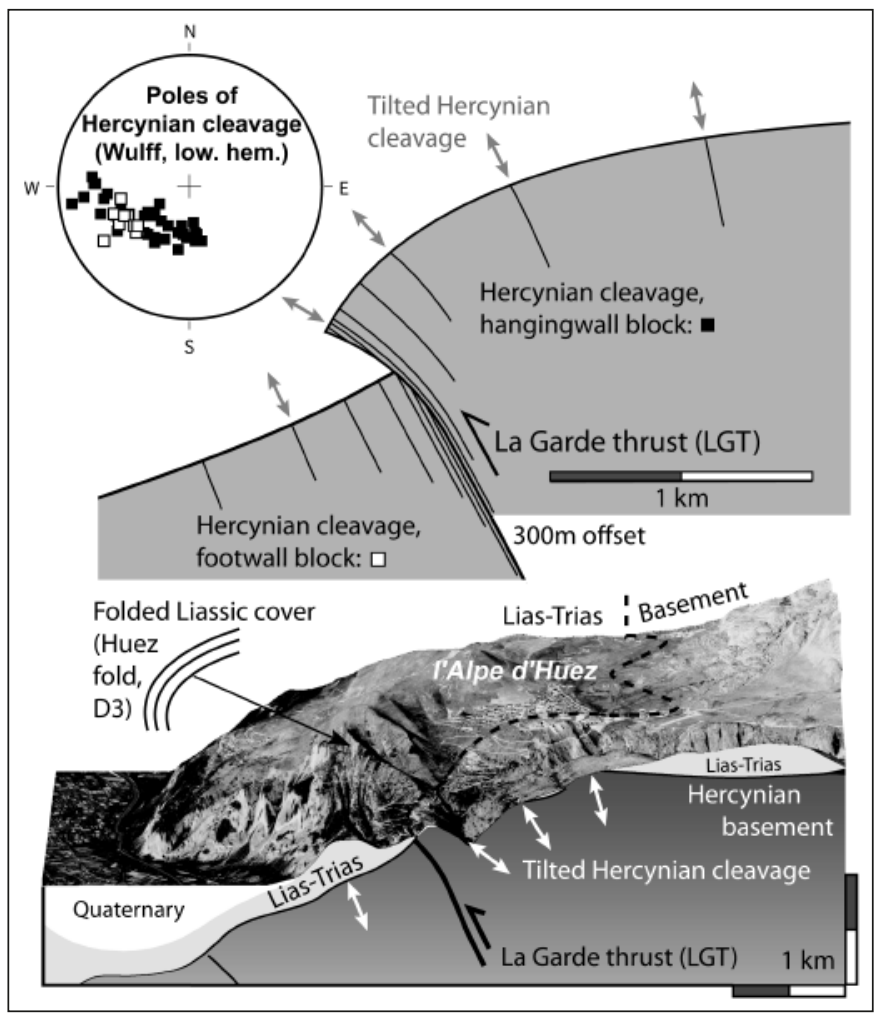

Fig. 8. Top: schematic cross-section of the La Garde thrust, with Alpine folding of Hercynian cleavage measured in the hanging wall block (stereogram). Bottom: block-diagram of the Huez fold-La Garde thrust area (satellite view over DEM).

ing in the northern and western parts of the modelled area. The strongest compressional deformation of the interface together with its highest altitude is observed in the southeastern part of the area, in the vicinity of the Pelvoux massif. Cross sections extracted from this model in different directions illustrate the variable relative influence of Tethyan and Alpine deformation in its present shape (Fig. 11): the tilted blocks geometry is visible on E-W and ENE-WSW profiles $n^{\circ} 1$ and 3 , whereas the E-W shortening component is more prominent to the south (profiles $n^{\circ} 2,4$ and 5). The latter produced basement uplift and forward short cuts, which are contractional faults slicing through the basement in the footwall of the normal faults. Along N-S profiles, trending parallel to the Jurassic fault blocks, the changes in elevation of the basement/cover interface are significant and show the occurrence of a N-S Alpine shortening component. The associated N-directed thrusts (Fig. 11) are D2 structures (Sue et al. 1999, and personal data). The compressional deformation is decreasing from the SE (A, profile 6) to the NW (C, profile 8 ). The A, B, C and D uplifted massifs lie in the hanging wall of both north-directed and west-directed thrusts, which suggests that this SE-NW gradient is due to partitioning between N-S and E-W shortening events. This is in good agreement with the field data presented above, and corresponds to 
D2 and D3 events, respectively. The Grandes Rousses uplift (E) is mainly due to E-W shortening, a conjugate result of D3 and D4 events (\$3.2). This model shows that the southern closure of the Mizoën Jurassic half-graben is due to Alpine shortening, namely westward and northward thrusting. In the Bourg d'Oisans half graben, stratigraphic data suggest that the offset of the Ornon Jurassic fault was decreasing southwards (Gidon 1980; Bas 1985; Barféty 1988). Our field investigations and modelling concentrated in the northern termination of this half-graben. The Grandes Rousses massif shows both a horizontal curvature on its western side and a gradual uplift towards the central part of the massif. This uplift occurs within a conjugate strike-slip system, that is between (i) the Alpe d'Huez fault zone (AHF, Fig. 5c) including several $\mathrm{N} 120^{\circ}$ sinistral faults visible along the road to l'Alpe d'Huez, and the Belle Etoile reverse fault cutting the Belledonne basement (BEF), and (ii) the Rissiou dextral fault (RF). The Bourg d'Oisans syncline splits northwards into two branches on each side of the Rissiou block (unit b, Fig. 5c). The Rissiou fault (RF) is not connected to the Jurassic Ornon fault (OF) that runs northwards in the footwall of the BEF. Here is actually the northern termination of the Bourg d'Oisans graben which therefore cannot be interpreted as a pull-apart basin as proposed by Grand et al. (1985).

\section{Thermochronological constraints}

\subsection{Age of peak metamorphism}

Alpine metamorphic peak conditions are estimated at about $320{ }^{\circ} \mathrm{C}$ to $370{ }^{\circ} \mathrm{C}$ and 2 to $3.5 \mathrm{kbar}$, corresponding to a maximum overburden of 7 to $12 \mathrm{~km}$ (see discussion in Crouzet et al. 2001a). Surprisingly, the age of peak metamorphism in the studied area is not clearly constrained. It can be estimated from some debatable data in the literature: the K/Ar method gives a reset apparent age of $24 \mathrm{Ma}$ from biotites of the Belledonne massif (Demeulemeester et al 1986); the $<2 \mu$ m clay fraction of Liassic rocks dated using the same method gives 26.5 Ma (Nziengui 1993). The thermo-palaeomagnetic record starts at 24.1 Ma in the Bourg d'Oisans area (Crouzet et al. 2001a), thus, the metamorphic peak was reached earlier, and it may correspond to the thermal overprint at $26.5 \mathrm{Ma}$ or may be even older.

\subsection{Rotation tested using re-interpretation of palaeomagnetic data}

The palaeomagnetic interpretation of Crouzet et al. (1996) was focused on tilting around a horizontal axis. The magnetic mineralogy, the procedure and treatments used are extensively
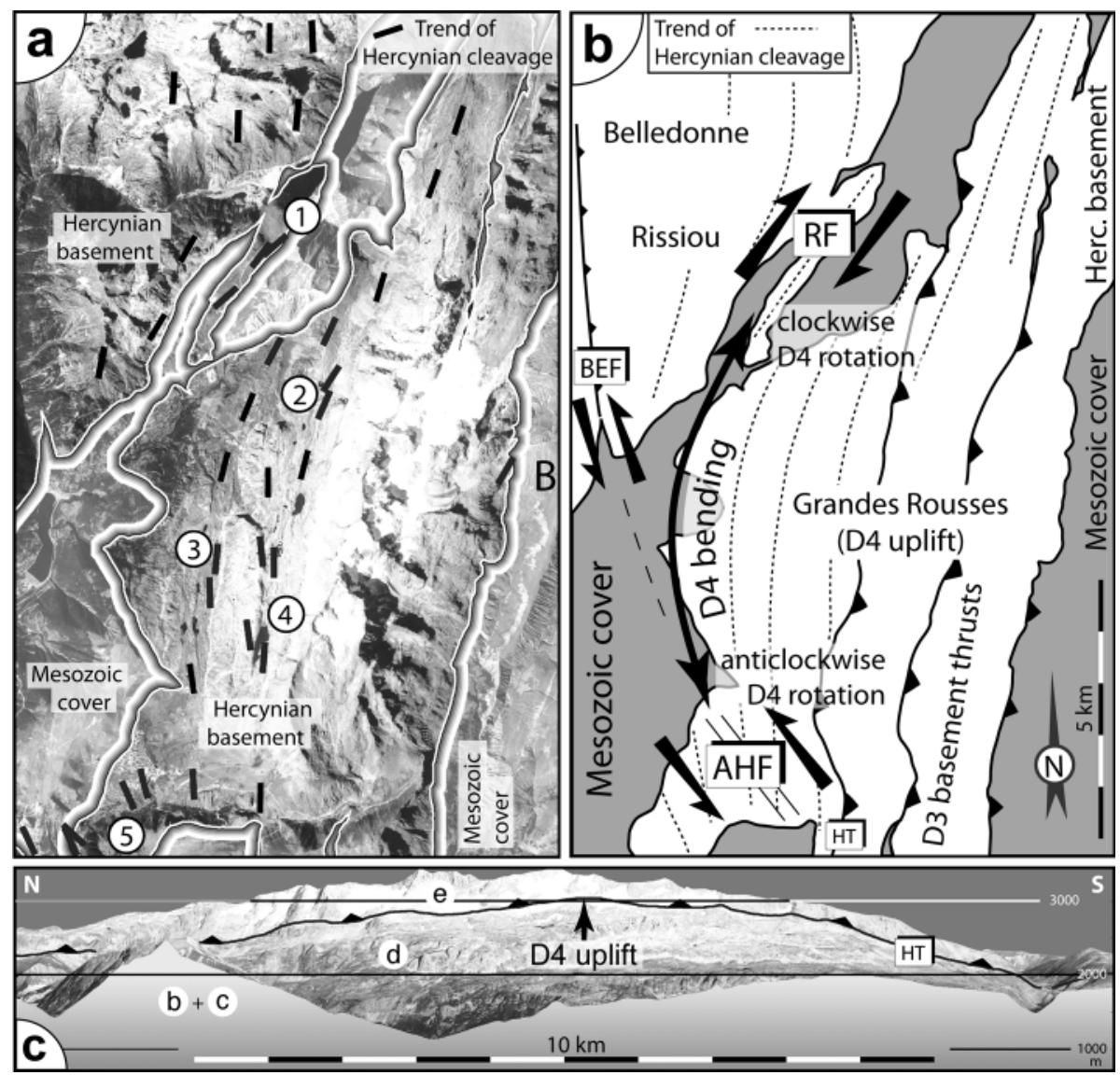

Fig. 9. Alpine fold trends and Hercynian grain between the Grandes Rousses and Belledonne massifs. a) Satellite view with location of five sites showing a gradual change in orientation of the late Hercynian cleavage from north to south (stereoplots in Fig. 10). Sites location: (1) Sabot pass, (2) from Couard pass to Jasse lake, (3) above Besson lake, (4) Blanc lake, (5) road to l'Alpe d'Huez. b) Simplified sketch map showing the trend of late Hercynian cleavage (white areas: basement outcrops), bended within two late Alpine conjugate strike-slip fault boundaries (RF: Rissiou fault; AHF: Alpe d'Huez fault; BEF: Belle Etoile fault). c) Synthetic, horizontal perspective view of the Grandes Rousses bulge from West, with no vertical exaggeration. Updoming is probably associated with bending during $\mathrm{D} 4$, as a compensation of westward displacement of the Grandes Rousses massif within the conjugate RF and AHF/BEF fault zones, coeval with the curvature of its western side (Fig. 9b). The D3 Herpie thrust (HT) is involved in bulging.

S98 T. Dumont et al. 


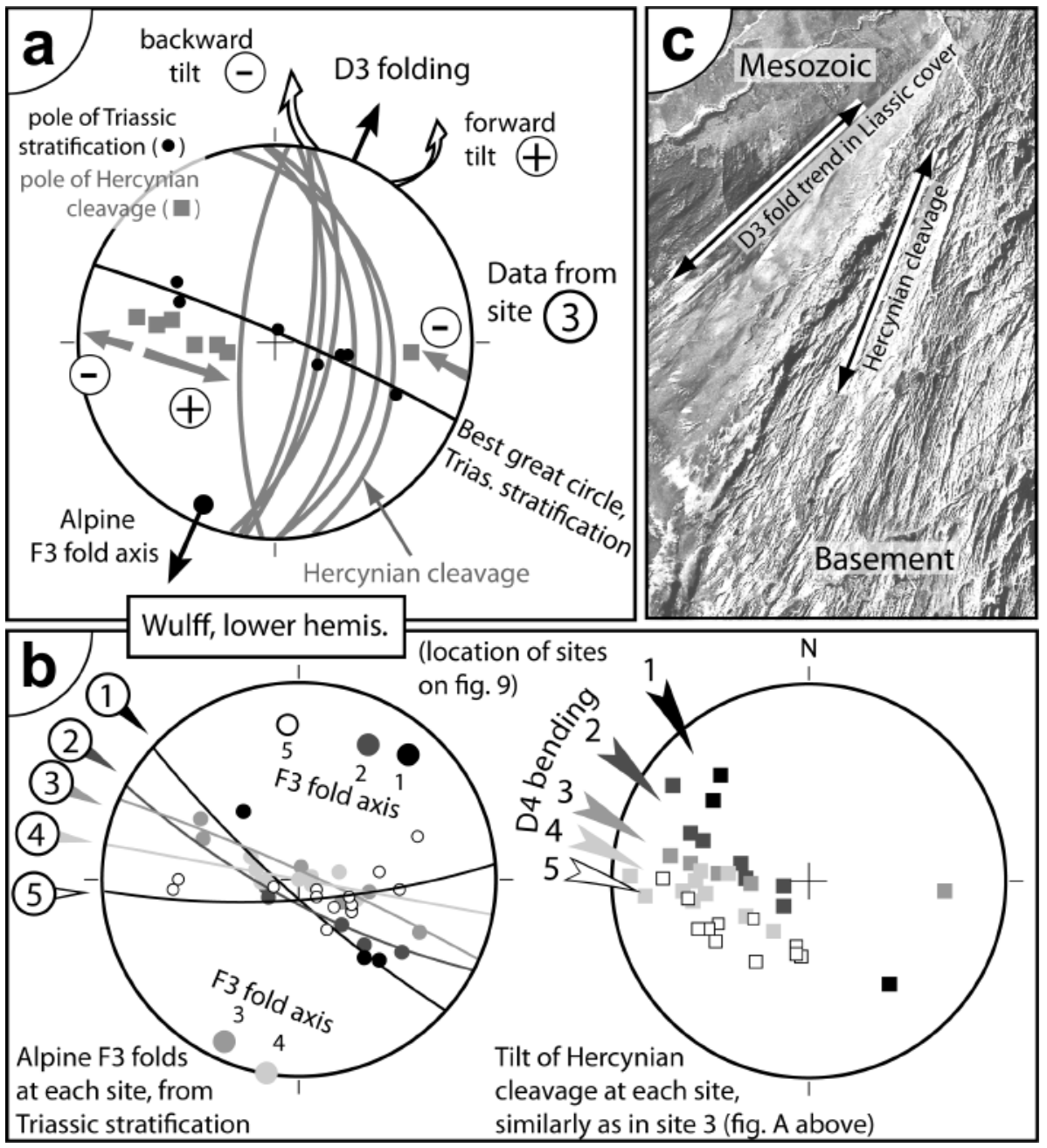

Fig. 10. a) Microstructures at site 3 (Fig. 9a): the plotted data show an Alpine (D3) folding of Hercynian cleavage, whose strike was initially different from the fold axis (initial obliquity of about $15^{\circ}$ ), so that the poles of Hercynian cleavage are scattered along small circles. b) Repeated observation from the five sites: both Hercynian cleavage and Alpine (D3) fold axes display a gradual clockwise rotation from south to north, approaching the Sabot wrench zone. Thus this is a late Alpine feature, assigned to D4. c) Detail aerial view of the northern Grandes Rousses area, showing about $\sim 20^{\circ}$ discordance between the strike of Hercynian cleavage and Alpine fold trends in the Liassic cover. described in other papers (Crouzet et al. 1996,1999 and 2001b). Here these data are re-interpreted and some new data are presented (Table 1) in order to test the hypothesis of recent rotation obtained from interpretation of our 3D model and structural data. The investigated sites are split into a northern and a southern group (location Fig. 3) corresponding to areas 1 and 3 of Crouzet et al. (1996), respectively. These sites were selected using the following criteria: (1) sites definitely tilted (Crouzet et al. 1996) and sites with $\mathrm{k}<10$ were not taken into consideration; (2) only sites from the lower Liassic formation were used (except area 4 of Crouzet et al. 1996), because they are closer to the basement/cover interface. The mean data for these two groups are the following:

- Southern group (Fig. 3; Tables $1 \&$ 2, area 3): the mean direction $\left(\mathrm{D}=350.0^{\circ}, \mathrm{I}=52.5^{\circ}, \mathrm{k}=76, \alpha 95=6.0\right)$ shows a significant apparent counter-clockwise rotation of $17.7^{\circ} \pm 8.5^{\circ}$ (Table 2) with respect to the expected direction at $\sim 25 \mathrm{Ma}$ $(\mathrm{D}=7.7 \pm 3.9 ; \mathrm{I}=58.3 \pm 2.7 ;$ a95 $=2.0)$ calculated after the apparent polar wander path for stable Europe (Besse and Courtillot 1991).
- Northern group (Fig. 3; Tables $1 \&$ 2, area 1): the mean palaeomagnetic direction is $\mathrm{D}=359.5^{\circ}, \mathrm{I}=53.2^{\circ}, \mathrm{k}=559$, $\alpha 95=2.6$. It also shows a significant rotation of $8.2^{\circ} \pm 4.6^{\circ}$ from the expected direction (Table 2).

Table 1. New paleomagnetic site characteristics. X, Y Lambert zone III coordinates; Z: altitude in m; N: number of samples used; Dec (Inc): Geographic declination (inclination) of the characteristic remanent magnetisation; $\mathrm{k}$ : precision parameter; $\alpha 95$ : confidence cone for a $95 \%$ level; areas are defined according to Crouzet et al.,(1996). A new area corresponding to Villard Notre Dame is introduced (sites BA, BB, BC).

\begin{tabular}{lccrrrrrrr}
\hline Site & $\mathbf{X}$ & $\mathbf{Y}$ & \multicolumn{1}{c}{$\mathbf{Z}$} & $\mathbf{N}$ & $\mathbf{D e c}$ & $\mathbf{I n c}$ & $\mathbf{K}$ & $\alpha \mathbf{9 5}$ & area \\
\hline 47 & 891.34 & 3321.12 & 780 & 6 & 1.0 & 49.8 & 492.6 & 3.0 & 1 \\
$48+49$ & 889.77 & 3320.00 & 740 & 13 & 3.9 & 56.4 & 13.8 & 11.6 & 1 \\
50 & 887.31 & 3314.92 & 1400 & 4 & 169.7 & -58.2 & 179.1 & 6.9 & 4 \\
51 & 887.38 & 3315.08 & 1550 & 5 & 173.9 & -24.9 & 4.8 & 38.8 & 4 \\
52 & 894.94 & 3326.43 & 1740 & 10 & 358.9 & 52.5 & 52.8 & 6.7 & 1 \\
53 & 888.00 & 3314.92 & 1445 & 7 & 190.7 & -62.3 & 120.0 & 5.5 & 4 \\
BA & 891.80 & 3307.95 & 1465 & 5 & 187.3 & -52.5 & 18.9 & 18.1 & 6 \\
BB & 891.81 & 3307.90 & 1500 & 5 & 193.5 & -50.7 & 57.1 & 10.2 & 6 \\
BC & 891.83 & 3307.85 & 1480 & 7 & 191.1 & -57.5 & 87.3 & 6.5 & 6 \\
\hline
\end{tabular}


The differential rotation between the southern and northern groups is $9.5^{\circ} \pm 8.6^{\circ}$. This rotation is significant at $95 \%$ confidence. Therefore, the northern sites underwent a clockwise rotation with respect to the southern sites, which is consistent with the structural and kinematic observations discussed above. Additional sampling was carried out on the SW part of the study area:

- The mean directions for areas 4 (Oulles road) and 5 (Villard-Reymond), located in the western part of the Bourg d'Oisans syncline, do not show any significant rotation with respect to stable Europe since $\sim 25 \mathrm{Ma}$. Thus D4 rotations occurred only in front of the Grandes Rousses bulge, as expected from the model discussed in $\S 4.2$.

- Area 6 samples were taken in the lower Liassic beds in the footwall of the D2 Villard Notre Dame thrust (Desthieux \& Vernet 1968), in order to test the influence of such structure on the magnetization direction. The samples from both limbs of a D2 fold show no significant rotation with respect to the expected direction of stable Europe (Table 2). This shows that northward thrusting associated with D2 occurred before the acquisition of magnetization.

\subsection{Age of deformation stages}

It has been demonstrated that the magnetization carried by pyrrhotite in the Bourg d'Oisans area is of thermal origin and was acquired during cooling in a temperature/time range between $>320^{\circ} \mathrm{C}$ at $24.1 \mathrm{Ma}$ to around $220^{\circ} \mathrm{C}$ at $20 \mathrm{Ma}$ (Crouzet 1997; Crouzet et al. 1999, 2001a and b). As stated above, magnetization postdates D2 deformation. The fold test is also negative concerning the Huez F3 fold (Crouzet et al. 1996), therefore, magnetization also postdates D3. Therefore, deformations D1 to D3 must be older than 24.1 Ma. The Zijderveld diagrams of most of the thermally demagnetized samples are linear between the pyrrhotite Curie temperature of $320^{\circ} \mathrm{C}$ and $150{ }^{\circ} \mathrm{C}$. Consequently, no deformation seems to have occurred during this cooling interval. The $150{ }^{\circ} \mathrm{C}$ isotherm may have been reached at about 9 to $13 \mathrm{Ma}$ according to Sabil (1995) and Crouzet et al. (1996). Rotation and tilting which have affected the palaeomagnetic record and which correspond to D4 deformation, correlated with the Grandes Rousses bulge uplift and bending, must then be younger than $13 \mathrm{Ma}$. The final exhumation is upper Miocene in age $(9.3 \pm 1 \mathrm{Ma}$ and $5.8 \pm 0.7 \mathrm{Ma}$ AFT ages: Sabil 1995).

\section{Discussion}

\subsection{Mesozoic fault pattern: a result of oblique extensional reactivation of Hercynian fabric}

The structural and kinematic data demonstrate that the shape of the Bourg d'Oisans Jurassic basin must have been significantly distorted by Alpine events. The western sidewall, corresponding to the N-S Ornon boundary fault (OF) south of the Romanche valley, can be followed further north, in the footwall of the BEF (Eau Dolle syncline, Fig. 4a). Its N-S trend parallels the late Hercynian foliation, but conjugate strike-slip and/or reverse faulting on both sides of the Rissiou basement massif (area b, Fig. $3 \& 4$ ), has strongly distorted the pre-Alpine geometry of the northern Bourg d'Oisans basin. Evidence of synrift extensional deformation is found between the Rissiou and the northern Grandes Rousses massifs (Col du Sabot area c, Fig. 3 \& 4): an east-dipping Liassic normal fault was located between unit c (Col du Sabot highly condensed lower Liassic series; Chevalier et al. 2003) and unit d (Aiguillettes thick series, Fig. 7c). This Sabot Liassic fault (SF, Fig. 4a) coincides with highly deformable basement (Sabot anticline schists, Fig. 4a \& $5 c$ ), located between two late-Hercynian granites (southern termination of Sept Laux granite and Alpette granite), which favoured the distortion of Tethyan structures in this area. A tentative pre-Alpine restoration is given in Fig. 12a. Basement deformation in the Sabot unit (c) and the curvature of the western Grandes Rousses unit (d) were taken into consideration. E-W shortening of about $50 \%$ is in agreement with the deformation measured in the Jurassic series (Gratier \& Vialon 1980). In this model, the Sabot paleofault (SF) died out southwards beneath the Liassic cover of the Bourg d'Oisans basin, and extension was then transferred to the Ornon paleofault (OF) further west (Fig. 12b). The syn-rift (early Liassic) depocentres were then aligned from the NE (Aiguillettes depocentre) to the SW (Bourg d'Oisans depocentre, and further on the Beaumont basin: Bas, 1988). Because there is evidence that the Sabot, Ornon and La Mure palaeofaults developed by extensional reactiva-

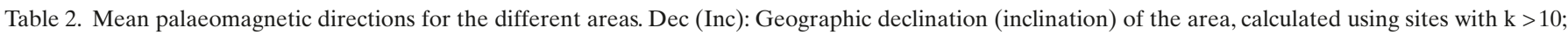

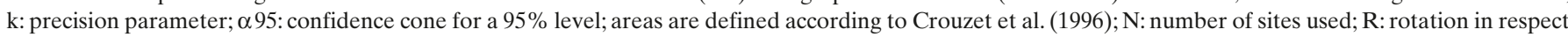

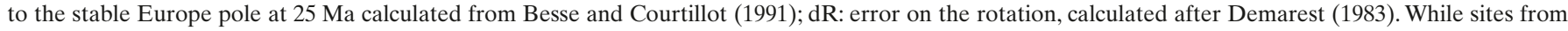

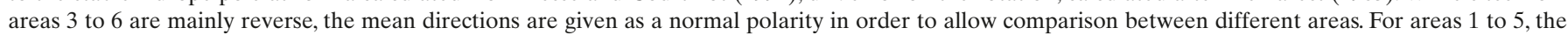
mean is calculated using data of Crouzet et al. (1996) and data presented in Table 1. Area 6 is newly defined in this paper.

\begin{tabular}{|c|c|c|c|c|c|c|c|c|}
\hline Area & Name & Dec & Inc & $\mathbf{k}$ & $\mathbf{A 9 5}$ & $\mathbf{N}$ & $\mathbf{R}$ & dR \\
\hline 1 & Allemond-Oz-Vaujany & 359.5 & 53.2 & 559 & 2.6 & 7 & -8.2 & 4.6 \\
\hline 3 & Huez & 350.0 & 52.5 & 76 & 6.0 & 9 & -17.7 & 8.5 \\
\hline 4 & Oulles & 3.6 & 56.5 & 88 & 4.1 & 15 & -4.1 & 6.7 \\
\hline 5 & Villard Reymond & 8.6 & 55.3 & 38 & 3.6 & 7 & 0.9 & 5.9 \\
\hline 6 & Villard Notre Dame & 10.7 & 53.6 & 410.4 & 6.1 & 3 & 3.0 & 8.8 \\
\hline
\end{tabular}

S100 T. Dumont et al. 
tion of N-S Hercynian foliation, we propose that this NE-SW distribution of depocenters is due to en-échelon pattern of the $\mathrm{N}-\mathrm{S}$ master faults, and we interpret this feature as a response of $\mathrm{N}-\mathrm{S}$ Hercynian foliation to obliquely oriented Jurassic extension (NW-SE; Lemoine et al. 1989). Such a fault relay geometry is observed in other natural examples (Cornfield \& Sharp 2000) and in analogue experiments (McClay \& White 1995).

\subsection{Regional restoration: major half-grabens in foliated basement}

A larger scale restored cross-section perpendicular to the Jurassic tilted blocks and to the Hercynian foliation is proposed in Fig. 13. The eastern half of this reconstruction is significantly different from previously published models (Lemoine et al. 1986; Gillcrist et al. 1987; Trift \& de Graciansky 1988; Chevalier 2002). Only two major boundary faults are involved, the La Mure and the Ornon faults. The syn-rift sequence is clearly pinching eastwards on the Grandes Rousses block, but further east the two limbs of the Mizoën syncline are not regarded as conjugate normal palaeofaults because they both display condensed, but conformable syn-rift sediments. Two small half-grabens are now buried beneath the Mizoën syncline and are exposed further south (see $\$ 6.4$, Fig. 14). We found no evidence to support the interpretation of the Meije and Combeynot massifs as syn-rift tilted blocks (Lemoine et al. 1986; Gillcrist et al. 1987), because all the areas east of the Grandes Rousses block and around the Pelvoux massif bear condensed syn-rift lower Liassic series (Barféty 1988; Corna et al. 1997; Chevalier 2002). Thus the eastern Dauphiné zone represented a large plateau without major fault blocks. This suggests that the offsets of the western Dauphiné faults (La Mure and Ornon) were transferred at depth to a flat detachment underlying the whole eastern Dauphiné area (Fig. 13), as proposed in different models (Gillcrist et al. 1987; Chevalier 2002). Considering the width of the western tilted blocks $(\sim 15 \mathrm{~km})$, this detachment may have occurred in the middle crust, either close to the brittle-ductile transition, or as a reactivation of a Hercynian low-angle thrust.

According to this reconstruction, Jurassic extension was accommodated in different ways in the western and eastern parts of the Dauphiné zone, corresponding to different types of basement. In the western area (central Oisans), the metamorphic units with synkinematic intrusions of early Carboniferous granites are extensively foliated. This regionally consistent $\mathrm{N}-\mathrm{S}$ striking, east-dipping foliation was conveniently oriented for extensional reactivation (negative inversion), and the major fault blocks developed here. In contrast, the eastern basement represented by the Pelvoux massif shows extensive late Carboniferous, late-orogenic granitic plutons (300 Ma; Guerrot \& Debon 2000) intruded at shallow depth. There, the early synrift series are always condensed, indicating that no major fault blocks developed. Further southeast, the Hercynian fabric is oriented NW-SE (south-eastern Pelvoux massif, Argentera massif), similarly to the syn-rift Jurassic basins in the southern
French Alps (Dardeau 1983). This also supports the interpretation that Hercynian foliation was a primary controlling factor in the development of tilted blocks.

\subsection{Multistage shortening: A proposed tectonic and geodynamic scenario}

The following sequence of events is proposed to explain the data (Fig. 15a):

Earliest compressional structures: a consequence of PyreneanProvence orogeny?

The Mesozoic cover of central Oisans was locally affected by top southwest transport and recumbent folding (D1), locally re-oriented along the Ornon Jurassic fault buttress. This early compressional event is consistent with the SW-directed basement-thrusting event well documented in the southern Pelvoux area (Gidon 1979; Ford 1996; Lazarre et al. 1996). There, this event pre-dates the deposition of late Eocene limestones. Thus this early phase D1 must also predate the emplacement of Alpine nappes and be older than the peak of low grade metamorphism in the Dauphiné.

Early collision stage: Northward to NNW-ward thrusting (Early Oligocene):

This event is hardly visible in the study area, but is a key feature for understanding the kinematics of the Western Alpine external zone. The Alpine realm suffered important $\mathrm{N}-\mathrm{S}$ contraction in response to Adria-Europe collision in late Eoceneearly Oligocene times (Lacassin 1989; Schmid \& Kissling 2000; Dèzes et al. 2004). Early Alpine northward to NW-ward thrusting and folding is documented in many places throughout the Alps: in the Helvetic zone (Dietrich \& Durney 1986; Ramsay 1989; Wildi \& Huggenberger 1993), in the Internal Zones (Caby 1973; Maury \& Ricou 1983; Merle \& Brun 1984; Merle et al. 1989; Platt et al. 1989b; Schmid et al 1996; Ceriani \& Schmid 2004) and in the Austro-Alpine realm (Froitzheim et al. 1994). N-directed thrusting is also known in the Pelvoux realm (Barbier 1956; Desthieux \& Vernet 1968; Bartoli et al. 1974; Gidon 1979; Gillcrist 1988; Barféty \& Gidon 1990; Pêcher et al. 1992; Ford 1996; Sue et al. 1998; Gidon 1999) but it has been generally confused with Pyrenean-Provence events. We propose that this D2 episode, which predates the onset of westward escape in the Western Alps but involves the late Eocene sediments, occurred in early Oligocene times, consistently with our palaeomagnetic record $(\$ 5.3)$. We also propose that this event is linked with the emplacement of the exotic early Alpine Embrunais-Ubaye nappes to the SE of the study area (2, Fig. 1). There, the Eocene flysch was buried to more than $7 \mathrm{~km}$ depth (south of the Pelvoux massif; Waibel 1990) and suffered local isoclinal folding in the footwall of these nappes (Prapic area, Orcières geological sheet; Debelmas et al. 1980). According to Kerckhove et al. (1978), 
the associated tectonic transport direction was towards the NW. Both these D2 structures and the nappes are overprinted by D3 SW-directed tectonic transport. The Penninic Romand and Chablais Prealps nappes were also emplaced in early Oligocene times towards the N to NW onto the external European units (Mosar et al. 1996; Bagnoud et al. 1998).

W-directed basement stacking and early stage of exhumation (Oligocene, $>24 \mathrm{Ma}$ ):

A sharp kinematic shift must have occurred between D2 and D3, since all the post-D2 deformations correspond to westward propagation of shortening. The eastern part of the Grandes Rousses area is affected by D3 high-angle basement thrusts that reactivate the $\mathrm{N}-\mathrm{S}$ trending late Hercynian lithological boundaries and cleavage (e.g. the Herpie thrust, HT, Fig. 4). D3 shortening is properly oriented to produce both short cuts of the Tethyan horsts and pinching of the syn-rift basins along the Belledonne-Taillefer, Jurassic-inherited buttress (Dumont et al. 1996). Greater amounts of inversion are observed in the Helvetics (Morcles nappe, Badertscher \& Burkhard 1998). In the study area, the offset of basement thrusts is generally less than $1 \mathrm{~km}$. They form ramp anticline features in the shallow part of the basement and their displacement is transferred to large-scale folds in the lower Liassic cover (Huez fold, Fig. 7b). This deformation still occurred at elevated temperatures, probably $>320^{\circ} \mathrm{C}$, because it predates the pyrrhotite magnetization (Crouzet et al. 1996 and 2001a). Thus D3 represents an early stage of the exhumation history, soon after the metamorphic peak which may have occurred in Oisans aroud $26 \mathrm{Ma}$ or earlier $(\$ 5)$. The latter is very likely related with the westward emplacement of the Internal Nappes stack onto the External zone along the Briançonnais Frontal Thrust (sensu Sue \& Tricart 2002; D3 activation of Roselend thrust according Ceriani et al. 2001 or D2 stage of Fügenschuh \& Schmid 2003) which occurred in early and middle Oligocene times, between $33 \mathrm{Ma}$ and 27.5 Ma (Tricart et al.2000; Ceriani et al.2001; Tricart 2004). The D3 westward tectonic transport of the Internal Nappes was strongly influenced by the Pelvoux basement bulge, previously thickened during D1 and D2 episodes (Gamond 1980; Tricart 1980). The propagation of this tectonic overload is also recorded in the Mt Blanc and the Argentera external massifs, which were buried to over $14 \mathrm{~km}$ at $22 \mathrm{Ma}$ (Leloup et al. 2005; Corsini et al. 2004).

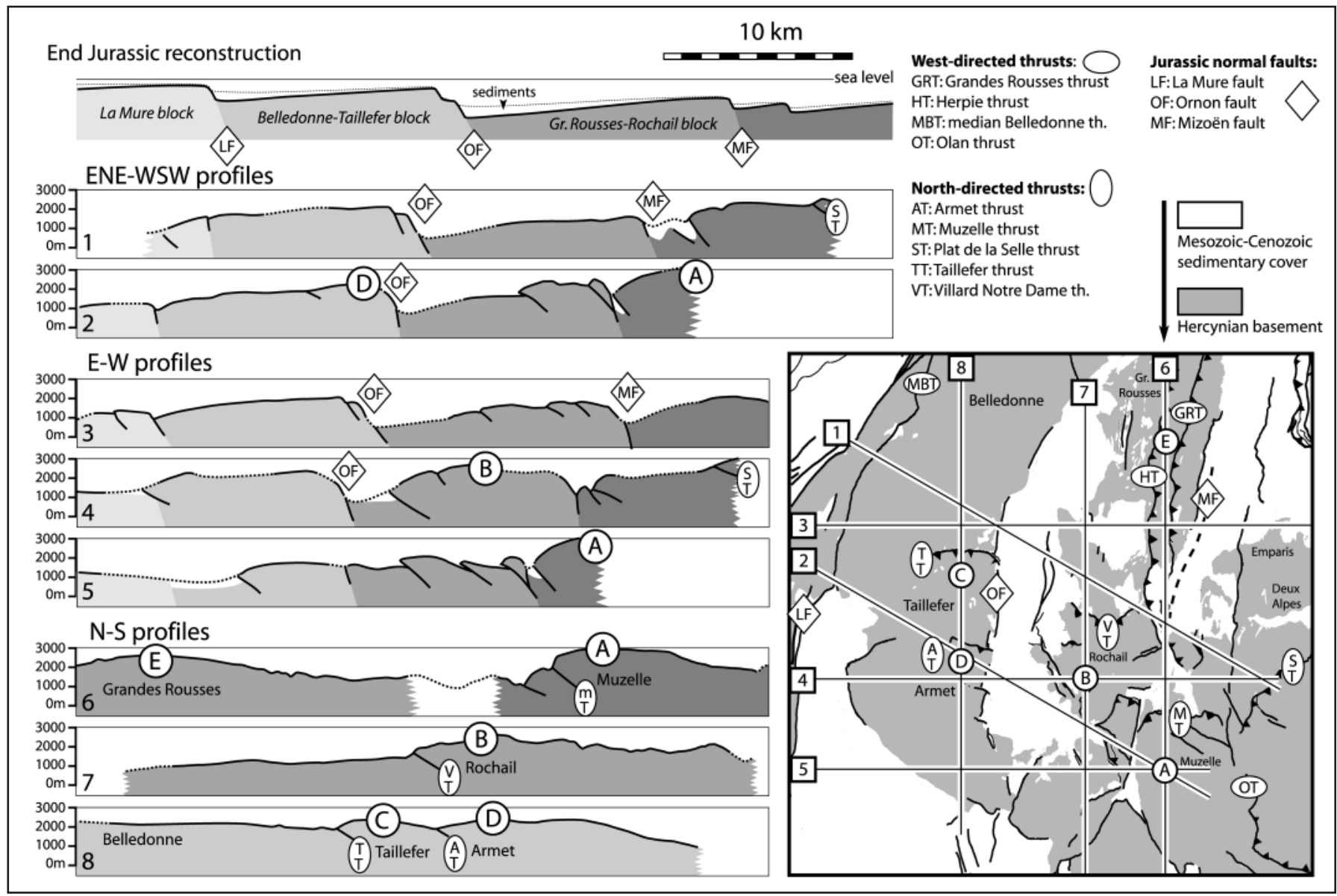

Fig. 11. Vertical cross-sections of the basement-cover interface extracted from the 3D model of Fig. 5b, with location shown in the sketch map corresponding to Fig. 2. On top is shown a reconstructed ENE-WSW profile at the end of Jurassic rifting. 
Buttressing and forward propagation of uplift (Middle-Late Miocene, <13 Ma):

According Crouzet et al. (1996 and 2001a), no deformation occurred during the main cooling interval from $320^{\circ} \mathrm{C}$ to $200{ }^{\circ} \mathrm{C}-$ $150{ }^{\circ} \mathrm{C}$. Structural and palaeomagnetic records indicate that post-D3 clockwise rotation and strike-slip faulting occurred between the Grandes Rousses and Belledonne basement blocks. D4 also produced long wavelength uplift of the Grandes Rousses massif, later than $10 \mathrm{Ma}$. The large scale anticlinal shape of this massif (Vernet 1965) formed at that time, as shown by opposite tilting of the palaeomagnetic vectors in the Liassic sedimentary cover (West side: Crouzet et al. 1996; East side: Lamarche et al. 1988). D4 in the Bourg d'Oisans and Grandes Rousses areas was enhanced by the uplift of the BelledonneTaillefer buttress, which increased shortening of sedimentary series with local backward folding. This recent exhumation of the Belledonne massif is documented by:

- The lack of basement rocks from the Belledonne massif in the Middle Miocene conglomerates of the proximal delta near Grenoble (Bocquet 1966).

- The upper Middle Miocene to Pliocene range of apatite fission-track data from the eastern Belledonne near the study area $(14.3 \pm 2.0$ to $4.2 \pm 0.5 \mathrm{Ma}$; Sabil 1995).

The uplift and subsequent increasing buttress effect to the east of the Belledonne-Taillefer massif is probably a consequence of the late Miocene transport of these external massifs above a crustal ramp, which accommodated the westward propagation of the Alpine orogen (Mugnier et al. 1990; Deville \& Chauvières 2000).
6.4 Interpretation of D2 shortening: an early, $N$-directed stage of Alpine collision

The Dauphiné crystalline basement in the study area is shortened and uplifted by several E-W, southward dipping highangle thrusts (Fig. 2, Fig. 11). Most of the highest peaks in the region are in the hanging wall of such structures. Our kinematic data from the Mesozoic cover indicate that this remarkable event occurred between D1 and D3, and the Eocene flysch is involved. Further south in the Lanchatra valley (Fig. 14, location Fig. 2), the Liassic strata in the footwall of the Muzelle EW thrust (MT, Fig. $11 \& 14$ ) are affected by both E-W and N-S shortening. Northward recumbent folding below this thrust affects an earlier cleavage and is overprinted by a younger one, namely D1 and D3, respectively. Thus MT is a D2 feature. Other D2 thrusts (ST, MT, VT, TT; Fig. 11) bear evidence for dextral strike-slip reactivation and/or deformation by E-W D3 shortening, and several of them crosscut older compressional structures. For example (Fig. 14), the hanging wall block above MT transports a huge D1 granitic-core anticline and previously shortened Tethyan tilted blocks are cut in its footwall.

Such perpendicular shifts in orientation of shortening were already noticed by Gillcrist (1988) and Sue et al. (1998). Together with Ford (1996) and Gidon (1999), they regarded all the N-S shortening features as related to pre-Late Eocene Pyrenean-Provence orogeny. Bravard \& Gidon (1979) proposed that the north-directed thrust system of the northeastern Pelvoux was active during Late Eocene, but the synsedimentary tectonic evidence is highly questionable according Butler (1992). In our opinion, two episodes with a N-S shortening component must be distinguished: a pre-Late Eocene event, so-called "Pyrenean-Provence", and an Early Oligocene, early Alpine event.

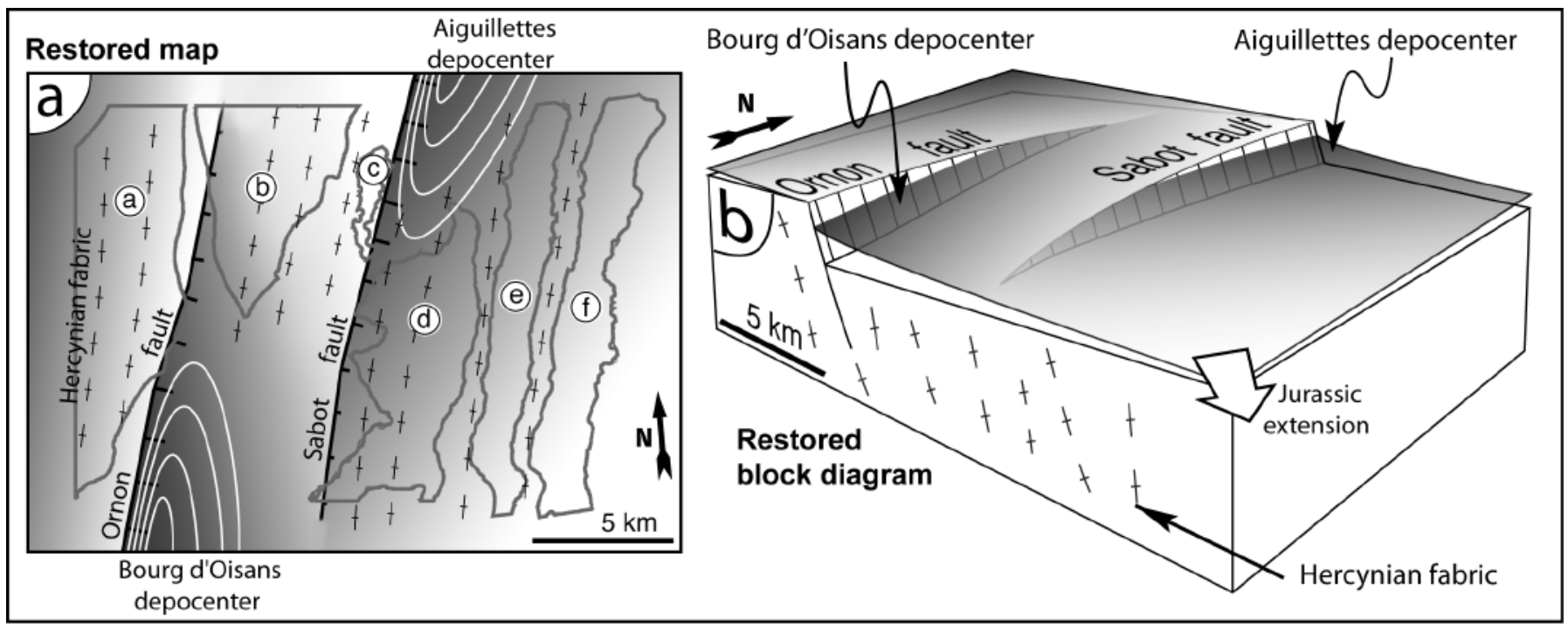

Fig. 12. The main structural units (a) to (f) corresponding to Fig. 3 \& $5 \mathrm{c}$ are restored in a pre-Alpine position based on semi-quantitative estimation of Alpine deformation (left). The superposition of the main Liassic faults and depocentres over this restored map leads to reconstruction b, right: the faults were subparallel to the late Hercynian fabric and close to N-S oriented. Extension was transferred laterally from the Sabot fault to the Ornon fault. This could be due to the initial obliquity between the involved Hercynian fabric and NW-SE Jurassic extension. 


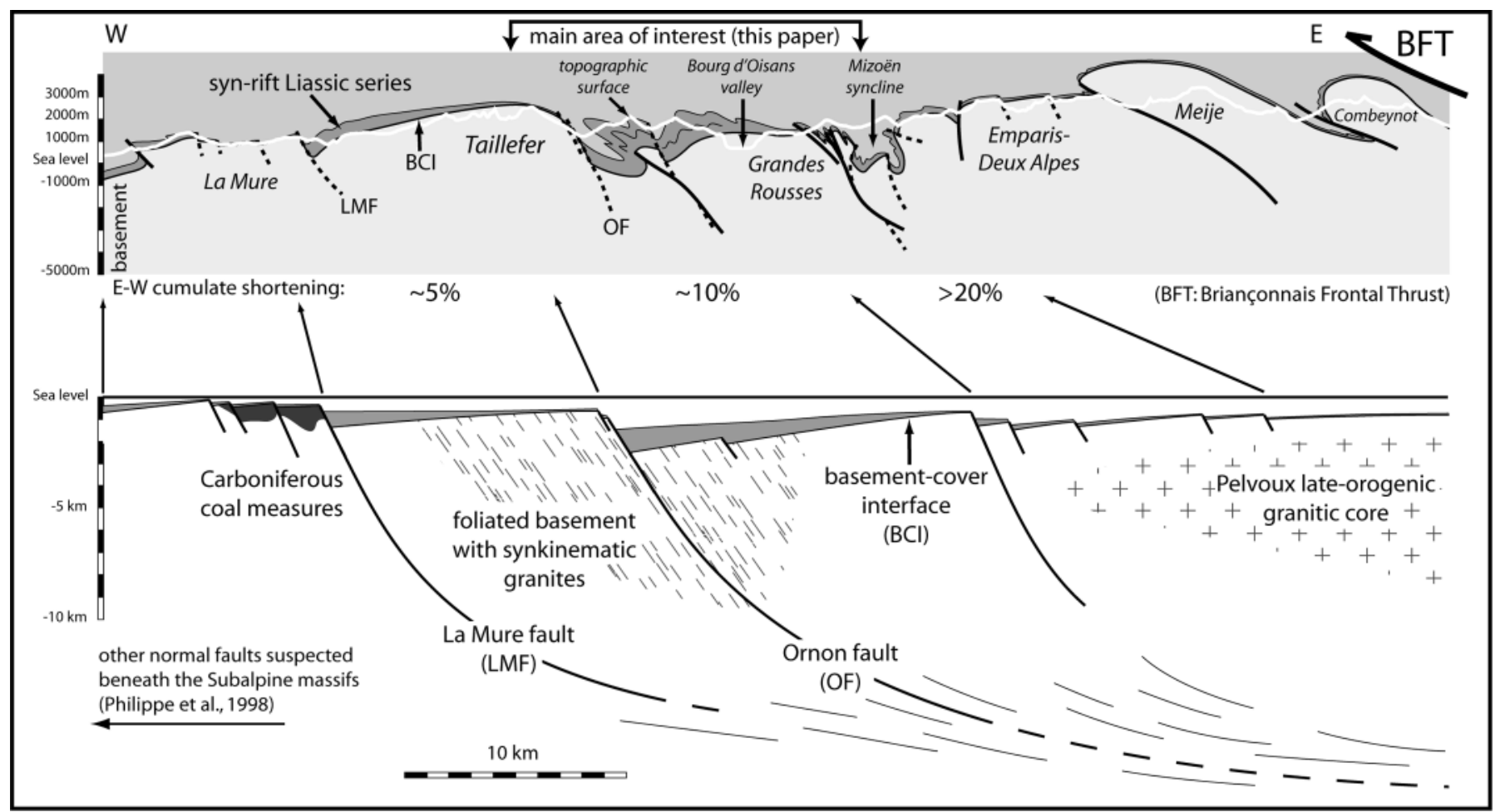

Fig. 13. E-W cross-section of the whole Dauphiné zone, with proposed reconstruction during the early Jurassic, based on the distribution and facies of early syn-rift sediments. Large-scale blocks tilting occurred only in the western part, as a suspected consequence of specific basement lithologies and postulated connection of the major normal faults with a mid-crustal detachment level.

The former (D1) is dominantly S-directed and is sealed by the Priabonian beds in southern Pelvoux (Gidon 1979; Ford 1996; Gupta 1997). The latter (D2) overprints D1 features in many places, it is north to NW-directed and is nowhere sealed by the Late Eocene sediments. It clearly deformed the Nummulitic formations both in the eastern Pelvoux (Bravard 1982, and personal data) and in the southern Pelvoux area (Gidon \& Pairis 1981).

\subsection{Basement folding}

Despite metamorphic conditions lower than greenschist facies, the Dauphiné basement accommodated a significant amount of E-W shortening by large-scale folding, as shown by the contorted shape of the initially flat basement-cover interface in our 3D models. This feature has been considered of minor importance in some thin-skinned type models that emphasize brittle deformation (Butler 1984; Platt 1984), but kilometric-scale folds occur in the hanging wall of high-angle basement ramps, and even granitic blocks show large wavelength folds: the Grandes Rousses massif is a $10 \mathrm{~km}$-wide basement anticline, and the Rochail massif is a granitic dome in the hanging wall of both $\mathrm{D} 2$ and $\mathrm{D} 3$ thrusts. The Pelvoux massif itself is a $5 \mathrm{~km}$-high basement bulge created by D1 and D2 N-S shortening, which suffered D3 underthrusting below the westward-propagating internal nappes (Gamond 1980; Tricart 1980). Since the conditions for ductility of granitic minerals were not reached in this region $(\$ 5.1)$, the «semi-ductile» deformation of basement must involve the following processes (i) pressure-solution for a prolonged period; and/or (ii) simple shear reactivation of the Hercynian foliation when it was optimally oriented (e.g. eastward dip favoured reverse reactivation during E-W shortening). The features observed here represent an incipient stage of basement folding much more developed in recumbent structures of some other external crystalline massifs (Aar-Gotthard massif, Pfiffner et al. 1990).

\subsection{Integration of our observations with the Alpine collisional evolution}

Two different nappes stacks are found to the S-SE and to the east of the Dauphiné basement massifs (Fig. 15b): (1) the Embrunais-Ubaye nappes which propagated north-westwards during the Early Oligocene (Kerckhove et al. 1978) and which experienced a $90^{\circ}$ anticlockwise rotation in transport direction (Merle \& Brun 1984), and (2) the Internal nappes transported westwards since the Early Oligocene (Ceriani et al. 2001; Tricart 2004). The latter clearly crosscuts the former south of the city of Briançon, and a sharp kinematic change is needed to explain this regional interference. We propose that this change is recorded in the footwall of both Alpine nappe systems (the Dauphiné basement massifs and sedimentary cover) by the D2/D3 shift. This shift occurred in the lowermost Oligocene according to some preliminary dating of synkinematic minerals in the eastern Pelvoux basement. D3 buried the study area to $\sim 10 \mathrm{~km}$ during Early Oligocene times. Palaeomagnetic data 


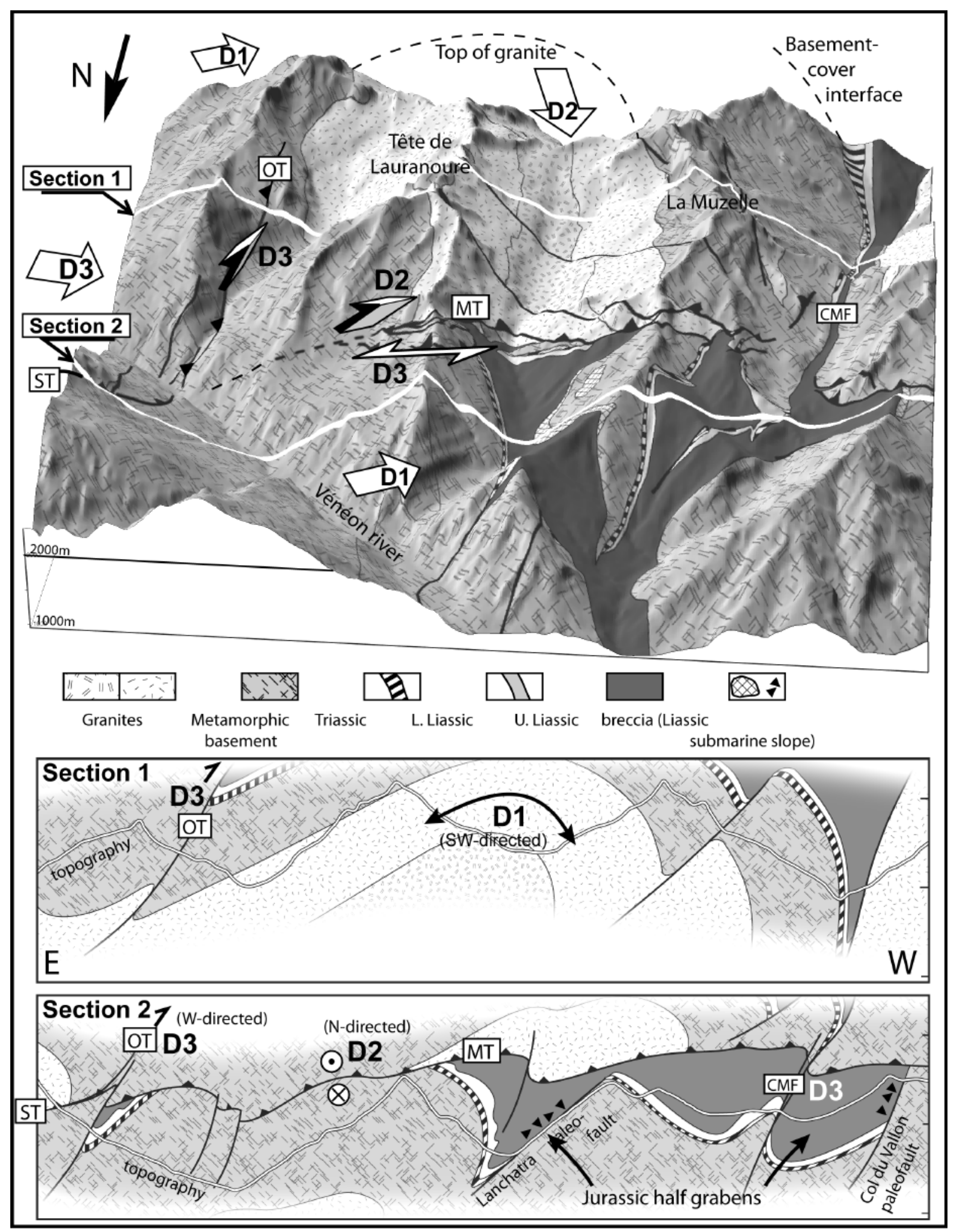

Fig. 14. Map scale evidence for deformation D2 in the Vénéon valley, to the south of the study area. Top: 3D geological map of the Tête de Lauranoure-Muzelle area, with no vertical exaggeration; view from the North with $45^{\circ}$ incidence. Southward dipping thrusts (ST: Selle thrust; MT: Muzelle thrust) look roughly aligned and rectilinear. They clearly cut a huge D1 basement anticline uplifted in the hanging wall block (bottom, section 1). They also cut two small-scale Jurassic halfgrabens still visible in the footwall (bottom, section 2), and which had been previously pinched as already stated by Gillcrist (1988). So deformation D2 postdates an earlier, D1 basement involved shortening event. ST and MT are in turn overprinted by a younger E-W shortening event (D3), which caused dextral strike-slip reactivation and crosscutting by more recent Olan thrust (OT) and Col de la Muzelle fault (CMF). 

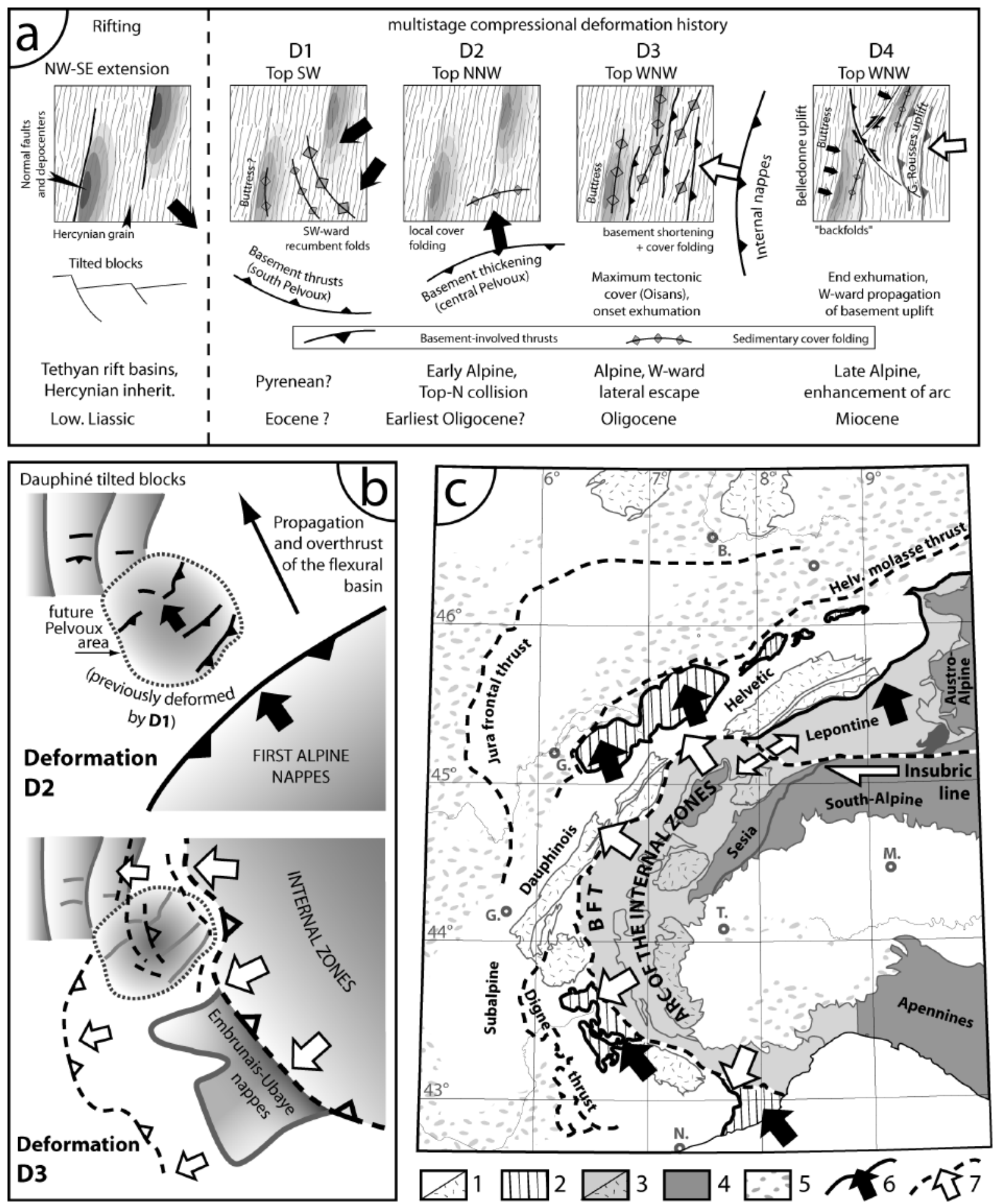

Fig. 15. a) Summary sketch of local deformation history. b) Regional interpretation including the Pelvoux area: an early Alpine nappe build-up was emplaced from the SE soon after the closure of the Late Eocene flexural basin; D2 shortening features (black thrusts) occurred in the footwall of this stack, represented by the Embrunais-Ubaye klippen. The latter was later on crosscut by the Internal Nappes stack propagating westwards in the study area (D3, dashed thrusts). c) Proposed integration in the Western Alps kinematics: D3 corresponds to the onset of lateral extrusion which gave birth to the arc of the Internal zones, linked with dextral motion along the Insubric line. 1: External zone, Mesozoic cover (white) and external basement massifs (dotted); 2: Early Alpine exotic units, from $\mathrm{N}$ to S: Prealpine nappes, Embrunais-Ubaye nappes \& Ligurian flyschs (first nappes stack, D2); 3: Internal zones (European margin and Ligurian Tethys derived units; internal basement massifs dotted); 4: Apulian-Adriatic derived units; 5: Tertiary foreland basins; 6: Early Alpine thrusts, related with the N-NW-directed collision phase (black arrows, D2); 7: Thrusts and faults related with the Oligocene westward extrusion phase (white arrows, D3); Briançonnais Frontal Thrust (BFT) dashed. 
(this paper and Crouzet et al., 2001a) recorded the initiation of unroofing in the footwall of the Internal zones during early Late Oligocene times, consistent with extensional reactivation of the Briançonnais Frontal Thrust (Tricart et al. 2000). Exhumation occurred with little deformation in the central Dauphiné until the lower Miocene, coeval with westward propagation of subsidence and deformation in the foreland molasse basins (Ménard 1988; Guellec et al. 1990; Deville et al. 1994). During late Miocene times, the exhumation of the Belledonne massif resulted in the study area in backward buttressing, renewed shortening at shallow structural levels (D4) and final exhumation and bending of the Grandes Rousses massif. Considering the whole Alpine realm (Fig. 15c), the major D2/D3 kinematic change can be correlated with the shift from N-directed (orogen-perpendicular) crustal stacking to westward (orogen-parallel) extrusion, which developed the western Alpine arc (Schmid \& Kissling 2000; Ford et al. 2006). The latter is marked since the Early Oligocene in the central Alps by transcurrent motion along the Insubric line (Schmid et al. 1989; Müller et al. 2001). In the Western Alps, this late collisional extrusion regime has extensively overprinted the initial build-up, but interferences with earlier stages are still visible in the external zone.

\section{Conclusions}

\section{Basement behaviour and Hercynian heritage:}

The different Alpine compressive stages reactivated the lateHercynian foliation depending on their relative orientation. The strongest reactivation was caused by maximum stress axis subperpendicular to the Hercynian grain: In the northern part of the Oisans region, the early Oligocene WNW-ward transport of Penninic nappes (D3) produced reverse faulting involving reactivation of the N-S trending, steeply east-dipping Hercynian cleavage, and subsequent basement thickening. D3 maximum stress axis was probably not strictly perpendicular to this cleavage, so that the coeval structures are trending $\sim 20^{\circ} \mathrm{W}$ with respect to the Hercynian fabric. Further southeast, D3 inversion is more strike-slip because the orientation of Hercynian fabric changes to NW-SE (southern Pelvoux and Argentera massifs). Large scale Hercynian structures such as late-orogenic pinched synclines and magmatic contacts (boundaries of granitic plutons) have also been reactivated during the Alpine orogeny. The late Hercynian granitoid massifs are mainly located in the hanging wall of northdirected D2 thrusts in the central Oisans region. The influence of granitoids distribution on the development of Alpine structures is also seen in the Aar massif (Pfiffner et al. 1990).

\section{Tethyan structures and inversion:}

Extensional reactivation of the Hercynian grain detected in the foreland (Roure \& Colletta 1996) was somehow underestimated in the Western Alps. Our reconstruction suggests that the syn-rift depocenters have been distributed en-échelon as a response to the obliquity of Jurassic extension (NW-SE) in the
$\mathrm{N}-\mathrm{S}$ foliated basement. The Alpine compressional reactivation of Tethyan fabric consists of incipient short cuts in the shallow basement, mostly important during the D3 deformation stage. There is little evidence for compressional reactivation of firstorder normal faults which were probably too steep (since they developed over the steeply dipping late Hercynian cleavage).

\section{Multistage shortening: lateral escape since middle Oligocene:}

The present structure results from four individual events separated by drastic changes in local shortening direction, which took place over a long time span. Three of them occurred before Neogene times: D1, D2 and D3, respectively directed SWwards, $\mathrm{N}$-wards and WNW-wards. The interpretation of the earliest event D1 is still speculative, but in the eastern and southern Pelvoux areas similar deformations occurred before Priabonian sedimentation, that is, before Alpine flexural subsidence. Thus a link with Pyrenean deformations in Provence is suspected. By contrast, we propose that D2 corresponds to an early stage of north-directed Alpine collision following the overthrusting of the Paleogene flexural basin during earliest Oligocene. The D3 stage occurred after a sharp kinematic change which probably marks the onset of westward extrusion in the W-Alpine arc.

\section{Acknowledgements}

Financial support from Total company under supervision of Jean-Claude Chermette is gratefully acknowledged. Interpretations were improved by discussions in the framework of GéoFrance3D Alpes. Structural data were processed using "Stem" software from Arnaud Pêcher. Gilles Ménard is acknowledged for discussions and help during palaeomagnetic sampling, and Pierre Rochette for giving access to one of us (CC) to the palaeo $\neg$ magnetic laboratory of the University of Aix Marseille III. One of us (JDC) would like to warmly acknowledge the Swiss National Science Foundation for several grants. The manuscript was improved by discussions with Stéphane Guillot and english reviewed by Matthias Bernet. Michel Guiraud and Mark Handy are gratefully acknowledged for their fruitful and thorough review.

\section{REFERENCES}

Aprahamian, J. 1988: Cartographie du métamorphisme faible à très faible dans les Alpes françaises externes par l'utilisation de la cristallinité de l'Illite. Geodynamica Acta 2, 25-32.

Badertscher, N. \& Burkhard, M. 1998: Inversion alpine du graben PermoCarbonifère de Salvan-Dorénaz et sa relation avec le chevauchement de la nappe de Morcles sus-jacente. Eclogae Geologicae Helvetiae 91, 359-373.

Bagnoud, A., Wernli, R. \& Sartori, M. 1998: Découverte de foraminifères planctoniques paléogènes dans la zone de Sion-Courmayeur à Sion (Valais, Suisse). Eclogae Geologicae Helvetiae 91, 421-429.

Barbier, R. 1956: L'importance de la tectonique anténummulitique dans la zone ultradauphinoise au nord du Pelvoux: la chaîne Arvinche. Bulletin de la Société géologique de France 6, 355-370.

Barbier, R., Barféty, J.C., Bocquet, A., Bordet, P., Le Fort, P., Meloux, J., Mouterde, R., Pêcher, A. \& Petiteville, M. 1973: Carte géologique de la France (1/50000), feuille La Grave (798), Bureau de Recherches géologiques et minières, Orléans.

Barféty, J.C. 1988: Le Jurassique dauphinois entre Durance et Rhône. Etude stratigraphique et géodynamique. Documents du Bureau de Recherches géologiques et minières $131,655 \mathrm{pp}$. 
Barféty, J.C., Bordet, P., Carme, F., Debelmas, J., Meloux, M., Montjuvent, G., Mouterde, R. \& Sarrot-Reynauld, J. 1972: Carte géologique de la France (1/50000), feuille Vizille (797), Bureau de Recherches géologiques et minières, Orléans.

Barféty, J.C. \& Gidon, M. 1983: La stratigraphie et la structure de la couverture dauphinoise au Sud de Bourg d'Oisans. Leurs relations avec les déformations synsédimentaires jurassiques. Géologie Alpine 59, 5-32.

Barféty, J.C. \& Gidon, M. 1984: Un exemple de sédimentation sur un abrupt de faille fossile: le Lias du versant Est du massif du Taillefer (Zone dauphinoise, Alpes occidentales). Revue de Géographie Physique et Géologie Dynamique 25, 267-276.

Barféty, J.-C. \& Gidon, M. 1990: La tectonique alpine du massif cristallin du Taillefer (Alpes occidentales françaises): découverte de chevauchements vers le nord. Géologie Alpine 66,1-9.

Barféty, J.-C., Gidon, M., Lemoine, M. \& Mouterde, R. 1979: Tectonique synsédimentaire liasique dans les massifs cristallins de la zone externe des Alpes occidentales françaises: la faille du col d'Ornon. Comptes Rendus de l'Académie des Sciences Paris 289, 1207-1210.

Barféty, J.C., Montjuvent, G., Pêcher, A. \& Carme, F. 1988: Carte géologique de la France (1/50000), feuille La Mure (821), Bureau de Recherches géologiques et minières, Orléans.

Barféty, J.C., Pêcher, A. \& coll. 1984: Carte géologique de la France (1/50000), feuille St. Christophe (822), Bureau de Recherches géologiques et minières, Orléans.

Bartoli,F., Pêcher,A. \& Vialon, P. 1974: Le chevauchement Meije-Muzelle et la répartition des domaines structuraux alpins du massif de l'Oisans, partie nord du Haut-Dauphiné cristallin. Géologie Alpine 50,17-26.

Bas, T. 1985: Caractéristiques du rifting liasique dans un secteur d'une marge passive de la Téthys: le haut-fond de La Mure et le bassin du Beaumont (Alpes occidentales). Unpublished PhD Thesis, Grenoble, 193pp.

Bas, T. 1988: Rifting liasique dans la marge passive téthysienne: le haut-fond de La Mure et le bassin du Beaumont (Alpes occidentales). Bulletin de la Société géologique de France 4, 717-724.

Besse, J. \& Courtillot, V. 1991: Revised and synthetic apparent polar wander paths of the african, eurasian, north american and indian plates, and true polar wander since 200 Ma. Journal of Geophysical Research 96, 40294050.

Bocquet, J. 1966: Le delta miocène de Voreppe. Etude des faciès conglomératiques du Miocène des environs de Grenoble. Travaux du Laboratoire de Géologie de Grenoble 42, 54-75.

Bravard, C. 1982: Données nouvelles sur la stratigraphie et la tectonique de la zone des Aiguilles d'Arves au nord du col du Lautaret. Géologie Alpine 58, 5-14.

Bravard, C. \& Gidon, M. 1979: La structure du revers oriental du massif du Pelvoux: observations et interprétations nouvelles. Géologie Alpine 55, 23-33.

Butler, R.W.H. 1984: Balanced cross-sections and their implications for the deep structure of the northwest Alps: reply. Journal of Structural Geology 5,607-612.

Butler, R.W.H. 1992: Thrust zone kinematics in a basement-cover imbricate stack; eastern Pelvoux Massif, French Alps. Journal of Structural Geology $14,29-40$.

Caby, R. 1973: Les plis transversaux dans les Alpes occidentales: implications pour la genèse de la chaîne alpine. Bulletin de la Société géologique de France 15, 624-634.

Ceriani, S., Fügenschuh, B. \& Schmidt, S. 2001: Multi-stage thrusting at the «Penninic Front» in the Western Alps between Mont Blanc and Pelvoux massifs. Geologische Rundschau 90, 685-702.

Ceriani, S. \& Schmid, S. 2004: From N-S collision to WNW-directed post-collisional thrusting and folding: Structural study of the Frontal Penninic Units in Savoie (Western Alps, France). Eclogae Geologicae Helvetiae 97, 347-369.

Chevalier, F. 2002: Caractérisation du fonctionnement d'une faille normale et de son impact sur l'enregistrement stratigraphique à partir de l'étude d'un hémigraben jurassique (Bourg d'Oisans, France). Unpublished PhD Thesis, Dijon.

Chevalier, F., Guiraud, M., Garcia, J.P., Dommergues, J.L., Quesne, D., Allemand, P. \& Dumont, T. 2003: Calculating the long-term displacement rates of a normal fault from the high-resolution stratigraphic record (early Tethyan rifting, French Alps). Terra Nova 15, 410-416.

Corna, M., Dommergues, J.L., Meister, C. \& Page, K. 1997: Les faunes d'ammonites du Jurassique inférieur (Hettangien, Sinémurien et Pliensbachien) au nord du massif des Ecrins (Oisans, Alpes occidentales françaises). Revue de Paléobiologie, Genève 16, 321-409.

Choukroune, P., Ballèvre, M., Cobbold, P., Gauthier, Y., Merle, O. \& Vuichard, J.-P. 1986: Deformation and motion in the Western Alpine arc. Tectonics $5,215-226$

Claudel, M.E. \& Dumont, T.1999: A record of multistage continental break-up on the Briançonnais marginal plateau (Western Alps): Early and MiddleLate Jurassic rifting. Eclogae Geologicae Helvetiae 92, 45-61.

Cornfield, S \& Sharp, I.R. 2000: Structural style and stratigraphic architecture of fault propagation folding in extensional settings; a seismic example from the Smorbukk area, Halten Terrace, Mid-Norway. Basin Research 12,329-341.

Corsini, M., Ruffet, G. \& Caby, R. 2004: Alpine and late-Hercynian geochronological constraints in the Argentera Massif (Western Alps). Eclogae Geologicae Helvetiae 97, 3-15.

Coward, M.P. \& Dietrich, D. 1989: Alpine tectonics, an overview. In: Coward, M.P., Dietrich, D. \& Park, R.G. (eds.), Alpine Tectonics, Geological Society of London, Special Publication n ${ }^{\circ} 45,1-29$.

Crouzet, C. 1997: Thermopaléomagnétisme: principe et applications (tectoniques, thermiques et géochronologique) à la zone dauphinoise interne (Alpes occidentales, France). Géologie Alpine, Mémoire Hors Série n ${ }^{\circ} 27$, $197 \mathrm{pp}$.

Crouzet, C., Ménard, G. \& Rochette, P. 1996: Post-Middle Miocene rotations recorded in the Bourg d'Oisans area, Western Alps, France by paleomagnetism. Tectonophysics 263, 137-148.

Crouzet, C., Ménard G. \& Rochette P. 1999: High precision three dimensional paleothermometry derived from paleomagnetic data in an Alpine metamorphic unit, Geology 27, 503-506.

Crouzet, C., Ménard, G. \& Rochette, P. 2001a: Cooling history of the Zone dauphinoise (Western Alps, France) deduced from the thermopaleomagnetic record: geodynamic implications. Tectonophysics 340, 79-93.

Crouzet, C., Rochette, P. \& Ménard, G. 2001b: Experimental evaluation of thermal recording of polarity reversals during metasediments uplift. Geophysical Journal International 145, 771-785.

Dardeau, G. 1983: Le Jurassique des Alpes Maritimes (France). Stratigraphie, paléogéographie, évolution du contexte structural à la jonction des dispositifs dauphinois, briançonnais et provençal. Unpublished Thèse d'Etat, Nice, $391 \mathrm{pp}$.

Debelmas, J., Kerckhove, C., Monjuvent, G., Mouterde, R. \& Pêcher, A. 1980: Carte géologique de la France (1/50000), feuille Orcières (846), Bureau de Recherches géologiques et minières, Orléans.

Demarest, H. 1983: Error analysis for the determination of tectonic rotation from paleomagnetic data. Journal of Geophysical Research 88, 43214328.

Demeulemeester, P., Roques, M., Giraud, P., Vivier, G. \& Bonhomme, M.G. 1986: Influence du métamorphisme alpin sur les âges isotopiques des biotites des massifs cristallins externes (Alpes françaises). Géologie Alpine $62,31-44$.

Desthieux, F. \& Vernet, J. 1968: Les failles inverses du flanc nord du Rochail. Géologie Alpine 44, 113-115.

Deville, E., Blanc, E., Tardy, M., Beck, C., Cousin, M. \& Ménard, G. 1994: Thrust propagation and syntectonic sedimentation in the Savoy Tertiary molasse basin (Alpine foreland). In: Mascle, A. (Ed.), Hydrocarbon and Petroleum Geology of France. Springer, Berlin, 269-280.

Deville, E. \& Chauvières, A. 2000: Thrust tectonics at the front of the western Alps: constraints provided by the processing of seismic reflection data along the Chambéry Transect. Comptes Rendus de l'Académie des Sciences Paris 331, 583-585.

Dèzes, P., Schmid, S. \& Ziegler, P.A. 2004: Evolution of the European Cenozoic Rift System: interaction of the Alpine and Pyrenean orogens with their foreland lithosphere. Tectonophysics 389, 1-33.

Dietrich, D. \& Durney, D.W. 1986: Change of direction of overthrust shear in the Helvetic nappes of western Switzerland. Journal of Structural Geology 8, 389-398. 
Dumont, T. 1998: Sea-Level changes and early rifting of a European Tethyan margin in the western Alps and Southeastern France. In. Graciansky, P.C. de, Hardenbol, J., Jacquin, T. \& Vail, P.R. (Eds): Mesozoïc and Cenozoic sequence stratigraphy of European Basins. Society of Economic Petrologists and Mineralogists, Special Publication 60, 623-642.

Dumont, T. \& Grand, T. 1987: Caractères communs entre l'évolution précoce d'une portion de marge passive fossile (marge européenne de la Téthys ligure, Alpes occidentales) et celle du rift de Suez. Comptes Rendus de l'Académie des Sciences Paris 305, 1369-1373.

Dumont, T., Vidal, G., Ustal, M. \& Tricart, P. 1997: L'interface socle-couverture dans la région de Bourg d'Oisans: modélisation numérique 3D. Documents du Bureau de Recherches géologiques et minières 274, $27-30$.

Dumont, T., Wieczorek, J. \& Bouillin, J.P. 1996: Inverted Mesozoic rift structures in the Polish Western Carpathians (High-Tatric units). Comparison with similar features in the Western Alps. Eclogae Geologicae Helvetiae $89,181-202$.

Ford, M. 1996: Kinematics and geometry of early Alpine, basement involved folds, SW Pelvoux Massif, SE France. Eclogae Geologicae Helvetiae 89, 269-295.

Ford, M., Duchêne, S., Gasquet, D. \& Vanderhaeghe, O. 2006: Two-phase orogenic convergence in the external and internal SW Alps. Journal of the Geological Society of London 163,1-12.

Froitzheim, N., Schmid, S.M. \& Conti, P. 1994: Repeated change from crustal shortening to orogenparallel extension in the Austroalpine units of Graubunden. Eclogae Geologicae Helvetiae 87, 559-612.

Fügenschuh, B. \& Schmid, S. 2003: Late stages of deformation and exhumation of an orogen constrained by fission-track data: a case study in the Western Alps. Geological Society of America Bulletin 115, 1425-1440.

Gamond, J.F.1980: Direction de déplacement et linéation: cas de la couverture sédimentaire dauphinoise orientale. Bulletin de la Société géologique de France 22, 429-436.

Gidon, M. 1979: Le rôle des étapes successives de déformation dans la tectonique alpine du massif du Pelvoux. Comptes Rendus de l'Académie des Sciences Paris 288, 803-806.

Gidon, M. 1980: Carte géologique de la France (1/50000), notice de la feuille St Bonnet (845). Bureau de Recherches géologiques et minières, Orléans, 43pp.

Gidon, M. 1999: L'origine des abrupts septentrionaux du Taillefer, massifs cristallins externes, Isère, France. Géologie Alpine 75, 103-109.

Gidon, M. \& Pairis, J.L. 1981: Nouvelles données sur la structures des écailles de Soleil Bœuf (bordure sud du massif du Pelvoux). Bull. Bureau de Recherches géologiques et minières 2,35-41.

Gillcrist, R. 1988: Mesozoic basin development and structural inversion in the French Western Alps. Unpublished PhD thesis, Imperial College, London, $430 \mathrm{pp}$.

Gillcrist, R., Coward, M. \& Mugnier, J.-L. 1987: Structural inversion and its controls: examples from the Alpine foreland and the French Alps. Geodynamica Acta 1,5-34.

Graciansky, P.C. de, \& Lemoine, M. 1988: Early Cretaceous extensional tectonics in the southwestern French Alps: a consequence of North-Atlantic rifting during Tethyan spreading. Bulletin de la Société géologique de France 5,733-738.

Grand, T. 1988: Mesozoic extensionnal inherited structures on the European margin of the Ligurian Tethys. The example of the Bourg d'Oisans halfgraben, western Alps. Bulletin de la Société géologique de France 4, 613-621.

Grand, T., Dumont, T. \& Pinto-Bull, F. 1985: Distensions liées au rifting téthysien et paléochamps de contrainte associés dans le bassin liasique de Bourg d'Oisans (Alpes occidentales). Bulletin de la Société géologique de France 4, 699-704.

Gratier, J.-P., Lejeune, B. \& Vergne, J.-L. 1973: Etude des déformations de la couverture et des bordures sédimentaires des massifs cristallins externes de Belledonne, des Grandes Rousses et du Pelvoux. Unpublished PhD thesis, Grenoble, 289 pp.

Gratier, J.-P., Pêcher, A. \& Vialon, P. 1978: Relations entre déformation interne et déplacement-glissement dans les roches. In: Mém. Bureau de Recherches géologiques et minières 91,207-214.
Gratier, J.-P. \& Vialon, P. 1975: Clivage schisteux et déformations: analyse d'un secteur clé du bassin mésozoïque de Bourg d'Oisans, Alpes dauphinoises. Géologie Alpine, Grenoble 51, 41-50.

Gratier, J.-P. \& Vialon, P. 1980: Deformation pattern in a heterogeneous material: folded and cleaved sedimentary cover immediatly overlying a cristalline basement, Oisans, French Alps. Tectonophysics 65, 151-180.

Guellec, S., Mugnier, J.-L., Tardy, M. \& Roure, F. 1990: Neogene evolution of the Western Alpine foreland in the light of Ecors data and balanced cross section. Mémoire Société géologique de France, nouvelle série 156, $165-184$.

Guerrot, C. \& Debon, F. 2000: U-Pb zircon dating of two contrasting Late Variscan plutonic suites from the Pelvoux massif (French Western Alps). Schweizerische Mineralogische und Petrographische Mitteilungen 80, 249-256.

Gupta, S. 1997: Tectonic control on paleovalley incision at the distal margin of the Early Tertiary Alpine foreland basin, south-east France. Journal of Sedimentary Research 67,1030-1043.

Kerckhove, C., Cochonat, P. \& Debelmas, J. 1978: Tectonique du soubassement parautochtone des nappes de l'Embrunais-Ubaye sur leur bordure occidentale, du Drac au Verdon. Géologie Alpine, Grenoble 54, 67-82.

Lacassin, R. 1989: Plate-scale kinematics and compatibility of crustal shear zones in the Alps. In: Coward, M.P., Dietrich, D. \& Park, R.G. (Eds.), Alpine Tectonics, Geological Society of London, Special Publication 45, 339-352.

Lamarche, G. 1987: Analyse microstructurale et fabrique magnétique. L'exemple des calcschiste et des flyschs de la zone dauphinoise. Alpes françaises. Unpublished PhD thesis, Université Joseph Fourier Grenoble, France, 168 pp.

Lamarche, G., Ménard, G. \& Rochette, P. 1988: Données paléomagnétiques sur le basculement tardif de la zone dauphinoise interne (Alpes occidentales). Comptes Rendus de l'Académie des Sciences Paris 306, 711-716.

Laubscher, H.P. 1988: The arcs of the Western Alps and the Northern Appennines: an updated view. Tectonophysics 146, 67-78.

Lazarre, J., Tricart, P., Courrioux, G. \& Ledru, P. 1996: Héritage téthysien et polyphasage alpin: réinterprétation tectonique du «synclinal» de l'Aiguille de Morges (massif du Pelvoux, Alpes occidentales, France). Comptes Rendus de l'Académie des Sciences Paris 323, 1051-1058.

Leloup, P.H., Arnaud, N., Sobel, E.R. \& Lacassin, R. 2005: Alpine thermal and structural evolution of the highest external cristalline massif: the Mont Blanc. Tectonics 24, TC4002, 26 p.

Lemoine, M., Gidon, M. \& Barféty, J.-C. 1981: Les Massifs Cristallins Externes des Alpes occidentales: d'anciens blocs basculés nés au Lias, lors du rifting téthysien. Comptes Rendus de l'Académie des Sciences Paris 292, 917-920.

Lemoine, M., Bas, T., Arnaud-Vanneau, A., Arnaud, H., Dumont, T., Gidon, M., Bourbon, M., de Graciansky, P.C., Rudckiewicz, J.L., Megard-Galli, J. \& Tricart, P. 1986: The continental margin of the Mesozoic Tethys in the Western Alps. Marine and Petroleum Geology 3, 179-199.

Lemoine, M., Dardeau, G., Delpech, P.Y., Dumont, T., de Graciansky, P.C., Graham, R., Jolivet, L., Roberts, D. \& Tricart, P. 1989: Extension syn-rift et failles transformantes jurassiques dans les Alpes occidentales. Comptes Rendus de l'Académie des Sciences Paris 309, 1711-1716.

Lickorish, W.H., Ford, M., Bürgisser, J. \& Cobbold, P.R. 2002: Arcuate thrust systems in sandbox experiments: A comparison to the external arcs of the Western Alps. Geological Society of America Bulletin 114,1089-1107.

Maury, P. \& Ricou,L.-E. 1983: Le décrochement subbriançonnais: une nouvelle interprétation de la limite externe-interne des Alpes franco-italiennes. Revue de Géographie Physique et Géologie Dynamique 24,3-22.

McClay, K.R. \& White, M.J. 1995: Analogue modelling of orthogonal and oblique rifting. Marine and Petroleum Geology 12,137-151.

Ménard, G. 1988: Structure et cinématique d'une chaîne de collision: les Alpes occidentales et centrales. Unpublished Doctorate thesis, Grenoble, $268 \mathrm{pp}$.

Merle, O. \& Brun, J.-P. 1984: The curved translation path of the Parpaillon nappe (French Alps). Journal of Structural Geology 6, 711-719.

Merle, O., Cobbold, P.R. \& Schmid, S. 1989: Tertiary kinematics in the Lepontine dome. In: Coward, M.P., Dietrich, D. \& Park, R.G. (Eds.): Al- 
pine Tectonics, Geological Society of London, Special Publication $\mathrm{n}^{\circ} 45$, $113-134$.

Mosar, J., Stampfli, G.M. \& Girod, F. 1996: Western Préalpes Médianes Romandes: Timing and structure. A review. Eclogae Geologicae Helvetiae $89,389-425$.

Mugnier, J.L., Guellec, S., Ménard, G., Roure, F., Tardy, M. \& Vialon, P. 1990: A crustal scale balanced cross-section through the external Alps deduced from the Ecors profile. Mémoire Société Géologique de France, nouvelle série 156, 203-216.

Müller, W., Prosser, G., Mancktelow, N., Villa, I., Kelly, S.P., Viola, G. \& Oberli, F. 2001: Geochronological constraints on the evolution of the Periadriatic Fault system (Alps). International Journal of Earth Sciences 90, 623-653.

Nziengui, J.-J. 1993: Excès d'argon radiogénique dans les quartz des fissures tectoniques: implications pour la datation des séries métamorphiques. L'exemple de la coupe de la Romanche, Alpes occidentales françaises. Unpublished PhD Thesis, Grenoble, 209 pp.

Pecher, A., Barféty, J.C. \& Gidon, M. 1992: Structures est-ouest anténummulitiques à la bordure orientale du masif des Ecrins-Pelvoux (Alpes françaises). Géologie alpine, Série spéciale Résumés de colloques n¹, 72-73.

Pfiffner, A.O., Klaper, E.M., Mayerat, A.M. \& Heitzmann, P. 1990: Structure of the basement-cover contact in the Swiss Alps. In: Roure, F., Heitzmann, P. \& Polino, R., Eds., Deep Structure of the Alps. Memoire Société Géologique de France 156, 247-262.

Philippe, Y., Deville, E. \& Mascle, A. 1998: Thin-skinned inversion tectonics at oblique basin margin: examples of the western Vercors and Chratreuse subalpine massifs (SE France). In: Mascle A., Puigdefabregas C., Luterbacher H.P. \& Fernandez M. (Eds.): Cenozoic Foreland basins of Western Europe. Geological Society of London, Special Publication 134, 239-262.

Platt, J.P. 1984: Balanced cross-sections and their implications for the deep structure of the northwest Alps: discussion. Journal of Structural Geology 5, 603-606.

Platt, J.P., Behrmann, J.H., Cunningham, P.C., Dewey, J.F., Helman, M., Parrish, M., Shepley, M.G., Wallis, S. \& Weston, P.J. 1989a: Kinematics of the Alpine arc and the motion history of Adria. Nature 337, 158-161.

Platt, J.P., Lister, G.S., Cunningham, P., Weston, P., Peel, F., Baudin, T. \& Dondey, H. 1989b: Thrusting and backthrusting in the Briançonnais domain of the western Alps. In: Coward, M.P., Dietrich, D. \& Park, R.G. (Eds.): Alpine Tectonics. Geological Society of London, Special Publication $45,135-152$.

Ramsay, J.G. 1989: Fold and fault geometry in the western Helvetic nappes of Switzerland and France and its implications for the evolution of the arc of the Western Alps. In: Coward, M.P., Dietrich, D. \& Park, R.G. (Eds.), Alpine Tectonics, Geological Society of London, Special Publication 45, 33-46.

Ratschbacher, L. 1989: Discussion on kinematics of the Alpine arc. Journal of the Geological Society of London 147, 572-575.

Ricou, L.-E. \& Siddans, A.-W.-B. 1986: Collision tectonics in the Westyern Alps. In: Coward, M.-P. \& Ries, A.-C., Eds., Collision tectonics, Geological Society of London, Special Publication 19, 229-244.

Roure, F. \& Colletta, B. 1996: Cenozoic inversion structures in the foreland of the Pyrenees and Alps. In: Ziegler, P.A. \& Horvath, F. (Eds.): Structure and prospects of Alpine basins and forelands, Peri-Tethys Memoire 2, Memoires du Museum d'Histoire Naturelle Paris 170,173-209.

Roux, M., Bourseau, J.P., Bas, T., Dumont, T., De Graciansky, P.C. \& Rudckiewicz, J.L. 1988: Bathymetric evolution of the Tethyan margin in the Western Alps, data from stalked crinoids: a reappreisal of eustatism problems during the Jurassic. Bulletin de la Société géologique de France 4, 633-641.

Sabil, N. 1995: La datation par traces de fission: aspects méthodologiques et applications thermochronologiques en contexte alpin et de marge continentale. Unpublished PhD Thesis, Grenoble, 238 pp.

Schmid, S.M., Aebli, H.R., Heller, F. \& Zingg, A. 1989: The role of the Periadriatic Line in the tectonic evolution of the Alps. In: Coward, M.P., Dietrich, D. \& Park, R.G. (Eds.): Alpine Tectonics, Geological Society of London, Special Publication 45, 153-171.

Schmid, S.M. \& Kissling, E. 2000: The arc of the Western Alps in the light of geophysical data on deep crustal structure. Tectonics 19, 62-85.
Schmid, S.M., Pfiffner, A., Froitzheim, N., Schönborn, G. \& Kissling, E. 1996: Geophysical-geological transect and tectonic evolution of the Swiss-Italian Alps. Tectonics 15, 1036-1064.

Sue, C. \& Tricart, P. 2002: Widespread post-nappe normal faulting in the Internal Western Alps: a new constraint on arc dynamics. Journal of the Geological Society of London 159, 61-70.

Sue, C., Tricart, P., Dumont, T. \& Pêcher, A. 1998: Raccourcissement polyphasé dans le massif du Pelvoux, Alpes occidentales: exemple du chevauchement de Villard Notre Dame. Comptes Rendus de l'Académie des Sciences Paris 324, 847-854.

Tapponnier, P. 1977: Evolution tectonique du système alpin en Méditerrannée: poinçonnement et écrasement rigide-plastique. Bulletin de la Société géologique de France 19, 437-460.

Thomas, J.C., Claudel, M., Collombet, M., Tricart, P., Chauvin, A. \& Dumont, T. 1999: First paleomagnetic data from the sedimentary cover of the French penninic Alps: evidence for Tertiary counterclockwise rotations in the Western Alps. Earth and Panetary Science Letters 171, 561-574.

Tricart, P. 1980: Tectoniques superposées dans les Alpes occidentales, au sud du Pelvoux. Evolution structurale d'une chaîne de collision. Thèse de Doctorat d'Etat, Strasbourg, $407 \mathrm{pp}$.

Tricart, P. 2004: From extension to transpression during final exhumation of the Pelvoux and Argentera massifs, Western Alps. Eclogae Geologicae Helvetiae 97, 429-439.

Tricart, P. \& Lemoine, M. 1986: From faulted blocks to megamullions and megaboudins. Tethyan heritage in the structure of the Western Alps. Tectonics $5,95-110$

Tricart, P., Schwartz, S., Sue, C., Poupeau, G. \& Lardeaux, J.M 2000: La dénudation tectonique de la zone ultradauphinoise et l'inversion du front briançonnais au sud-est du Pelvoux (Alpes occidentales): une dynamique miocène à actuelle. Bulletin de la Société géologique de France 172, $49-58$.

Trift, M. \& de Graciansky, P.C.1988: Aspects du rifting téthysien: petits grabens et mégabrèches du Domérien-Toarcien sur le plateau d'Emparis (Isère et Hautes Alpes). Bulletin de la Société géologique de France 4, 643-650.

Vernet, J. 1965: La zone Pelvoux-Argentera. Bull. Serv. Carte géol. France, 275, 131-424.

Vernet, J.1974: Sur la tectonique alpine des massifs cristallins dauphinois dans leur région culminante (Pelvoux, Grandes Rousses et leurs abords) et l'histoire de leur édification. Géologie Alpine 50,195-236.

Vialon, P. 1968: Clivages schisteux et déformations: répartition et genèse dans le bassin mésozoïque de Bourg d'Oisans. Géologie Alpine 44, 353-366.

Vialon, P. 1974: Les déformation synschisteuses superposées en Dauphiné. Leur place dans la collision des éléments du socle préalpin. Bulletin Suisse de Minéralogie et Petrographie 54, 663-690.

Vialon, P. 1986: Les déformations alpines de la couverture sédimentaire de blocs du socle cristallin basculés de Belledonne, Grandes Rousses et Pelvoux dans la région de Bourg d'Oisans. Réunion Extraordinaire de la Société Géologique de France: De la marge océanique à la chaîne de collision dans les Alpes du Dauphiné. Bulletin de la Société géologique de France 8, 197-231.

Vialon, P., Rochette, P. \& Ménard, G. 1989: Indentation and rotation in the Western Alpine arc. In: Coward, M.-P., Dietrich, D. \& Park, R.-G., (Eds.): Alpine Tectonics, Geological Society of London, Special Publication 45, 329-338.

Waibel,A.F. 1990: Sedimentology, petrographic variability and very-low-grade metamorphism of the Champsaur sandstone (Paleogene, Hautes Alpes, France). PhD Thesis, Geneva, $140 \mathrm{pp}$.

Wildi, W. \& Huggenberger, P. 1993: Reconstitution de la plate-forme européenne anté-orogénique de la Bresse aux Chaînes subalpines; éléments de cinématique alpine (France et Suisse orientale). Eclogae Geologicae Helvetiae 86, 47-64.

Manuscript received July 30, 2007

Revision accepted July 22, 2008

Published Online first November 1, 2008

Editorial Handling: Stefan Schmid, Stefan Bucher 